\title{
Law and Lawyers in the Incident Command System
}

\author{
Clifford J. Villa*
}

\section{INTRODUCTION}

"[I]f we can't do ICS, we cannot manage disasters." 1

On July 25, 2010, while much of the nation's attention remained riveted on the Deepwater Horizon disaster in the Gulf of Mexico, another environmental disaster began one thousand miles north in Marshall, Michigan. At 5:58 p.m. local time, an oil pipeline owned and operated by Enbridge Inc. ruptured in a wetland near a tributary of the Kalamazoo River. ${ }^{2}$ For seventeen hours, the rupture went unnoticed as oil poured from the pipeline into the river system. ${ }^{3}$ Carried by heavy rains, the oil spread over thirty river miles, ${ }^{4}$ overtopping dams, injuring wildlife,

\footnotetext{
* Assistant Regional Counsel, U.S. EPA Region 10; Adjunct Professor, Seattle University School of Law. As an EPA attorney, the author advises the EPA Region 10 emergency response program and is trained as a liaison officer in the Incident Command System. As an adjunct professor, the author teaches disaster law and environmental law courses. The views expressed in this Article are the author's alone and not necessarily positions of the EPA or the United States. The author thanks reviewers including Richard Delgado, Jacquie Hand, Marilyn Berger, Gregg Macey, and Hank McGee for their generous time and comments on prior drafts. Thanks also go to Jake Hinton, Seattle University School of Law Class of 2013, for superlative research assistance for this Article. This Article is for Julian, with hope that the next generation will always be ready.

1. Hurricane Katrina: A Nation Still UnPrePared, S. ReP. No. 109-322, at 563 (2006) [hereinafter A NATION STILl UnPREPARED] (citing Hurricane Katrina: Perspectives of FEMA's Operations Professionals: Hearing Before the S. Comm. on Homeland Sec. \& Gov'tl Affairs, 109th Cong. (2005) (statement of Scott Wells, Deputy Fed. Coordinating Officer, Fed. Emergency Mgmt. Agency)).

2. Nat'l Transp. Safety Bd., Pipeline Accident Report: Enbridge Incorporated HAZARDOUS LiQUid PIPELINE RUPTURE AND RELEASE (2010) (adopted July 2012).

3. Id.

4. Enbridge Pipeline Oil Spill Near Marshall, Michigan: Hearing Before the H. Comm. on Transp. \& Infrastructure, 111th Cong. 1 (2010) (statement of Lisa P. Jackson, Adm'r, Envtl. Prot. Agency) [hereinafter Jackson Statement]; see also EPA's Response to the Enbridge Oil Spill, ENVTL. PROT. AGENCY (Mar. 14, 2003), http://www.epa.gov/enbridgespill/.
} 
prompting local evacuations, and posing an ultimate threat to Lake Michigan downstream. ${ }^{5}$

The size and gravity of the Enbridge oil spill required a massive and immediate response, led by the U.S. Environmental Protection Agency (EPA). On July 27, 2010, within twenty-four hours of discovering the spill, the EPA regional office issued an order under the federal Clean Water Act $^{6}$ requiring Enbridge to provide for immediate actions to stop the oil discharge, contain the oil slick, and begin environmental cleanup. ${ }^{7}$ By the next day, July 28, 2010, hundreds of response personnel along with heavy equipment deployed to the scene, and Enbridge reported that it had stopped the oil from flowing into the river. By that time, however, nearly 850,000 gallons of oil had discharged into the river, requiring containment and cleanup operations that would continue for weeks, months, and ultimately years. ${ }^{8}$ Early operations included the use of "[m]ore than 200 boats," "85 miles of absorbent boom," and over 2,000 response personnel. ${ }^{9}$ Among this horde descending upon Marshall, Michigan, were, of course, the lawyers.

Like the legion of litigators drawn to the British Petroleum (BP) oil spill in the Gulf of Mexico in the same year, agency attorneys and corporate counsel leaped into action to address liability concerns flowing from the Enbridge oil spill in Michigan. The government would seek to recover its own response costs, ${ }^{10}$ and injured parties would seek compensation for a variety of losses. ${ }^{11}$ There might be civil fines, ${ }^{12}$ criminal penalties, ${ }^{13}$

5. EPA's Response to the Enbridge Oil Spill in Michigan (Environmental Response Television 2011) [hereinafter Enbridge Response] (on file with author). As the first EPA responder to arrive later described the scene, "I expected to see oil when I got here, and I did. And actually, there was no water in the creek. When I showed up, it was oil. It was straight, black, crude oil. And it was roiling, like in a whitewater river, but in a creek." Id. (statement of Jeff Kimble, EPA On-Scene Coordinator).

6. Clean Water Act § 311(c), 33 U.S.C. § 1321(c) (2011). Pursuant to Section 311(c) of the Clean Water Act, EPA may "direct or monitor all Federal, State, and private actions to remove a discharge" "of oil or a hazardous substance ... into or on the navigable waters [or] on the adjoining shorelines to the navigable waters" of the United States. See 33 U.S.C. $\S \S 1321$ (c)(1)(A)-(A)(ii), (B)(ii).

7. See In the Matter of Enbridge Energy, LP, Envtl. Prot. Agency, Docket No. CWA 1321-510-001 (July 27, 2010), available at http://www.epa.gov/region5/enbridgespill/ar/enbridge-AR1720.pdf.

8. In June 2012, after two full years of cleanup operations, federal, state, and local agencies announced the reopening of thirty-four miles of the Kalamazoo River to recreational use. Certain areas still remain closed to the public, however, and oil recovery operations continue as of this writing. See EPA Orders Enbridge to Perform Additional Dredging to Remove Oil from Kalamazoo

River, ENVTL. PROT. AGENCY (Mar. 14, 2013), http://www.epa.gov/region5/enbridge spill/index.html.

9. Enbridge Response, supra note 5.

10. See Oil Pollution Act $\S 1002(b)(1), 33$ U.S.C. $\S 2702(b)(1)$ (2010).

11. As of March 31, 2012, the Enbridge spill had reportedly cost the company $\$ 765$ million. At the same time, some twenty-five lawsuits had been filed against the company in federal and state 
or natural resource damages. ${ }^{14}$ Insurance claims would be filed, defenses would be invoked, and efforts would be made to share burdens all around.

These may be familiar roles for lawyers, drawing from established practice areas such as environmental law, torts, and insurance. ${ }^{15}$ However, in the emerging field of disaster law, ${ }^{16}$ lawyers from almost any discipline may find roles in what the literature of disaster law conceptualizes as a "disaster cycle," including preparedness, response, recovery, and mitigation. ${ }^{17}$ Within this cycle, conventional thinking confines lawyers to the recovery phase, in particular, pursuing claims or litigation seeking compensation from government agencies, insurance companies, or responsible parties. This association certainly has reason, as attested by the epic legal responses to $9 / 11,{ }^{18}$ Hurricane Katrina, ${ }^{19}$ and the Deepwater

courts. Matt Pearce, NTSB Report Enbridge's Response to Michigan Oil Spill Was "Poor," L.A. TIMES, July 10, 2012.

12. Clean Water Act § 311(b)(7), 33 U.S.C. § 1321(b)(7) (2010).

13. Id. $\S 309$ (c), 33 U.S.C. $\S 1319$ (c) (defining federal crimes and respective penalties including criminal fines and imprisonment).

14. See Oil Pollution Act $\S \S 1002(b)(2)(A), 1006,33$ U.S.C. $\S \S 2702(b)(2)(A), 2706$ (2010).

15. Recognizing the close connection between disaster law and more established areas of practice, the American Bar Association (ABA) and its various committees have sponsored a number of recent initiatives to promote the study and practice of disaster law. For example, the ABA has established a Special Committee on Disaster Response and Preparedness, which maintains a broad collection of disaster-related legal resources. See Committee on Disaster Response and Preparedness, AM. BAR Ass'N, www.americanbar.org/groups/committees/disaster.html (last visited Aug. 2, 2012).

16. The first legal textbook in this emerging field was published in 2006, the year following Hurricane Katrina, and is now in its second edition. DANIEL A. FARBER ET AL., DISASTER LAW AND POLICY (2d ed. 2010); see also Daniel Farber, Symposium Introduction: Navigating the Intersection of Environmental Law and Disaster Law, 2011 BYU L. REV. 1783, 1786-93 (arguing for disaster law as an emerging field of legal study, comparable to the field of environmental law in the 1960s and 70 s).

17. Professor Nicholson describes these elements succinctly as follows: "(1) mitigation, the lessening or avoidance of a hazard; (2) preparedness, including planning, training, and exercising; (3) response, referring to actions taken in the immediate aftermath of an event to deal with its effects; and (4) recovery, bringing circumstances back to at least the status they had prior to the emergency event." William C. Nicholson, Obtaining Competent Legal Advice: Challenges for Emergency Managers and Attorneys, 46 CAL. W. L. REV. 343, 346 (2010); see also Daniel A. Farber, Introduction: Legal Scholarship, the Disaster Cycle, and the Fukushima Accident, 23 DukE ENVTL. L. \& POL'Y F. 1 (2012) (illustrating the disaster cycle in context of Fukushima meltdown in Japan).

18. For an extraordinary film documentary examining compensation questions following $9 / 11$, see Out OF THE AsHES: 9/11 (Marilyn Berger, Exec. Producer, 2011) (discussing families of 9/11 victims and the role of lawyers respecting claims against the Victim Compensation Fund, created by Congress eleven days after terrorist strikes).

19. See, e.g., Eugene Benick, The Flood After the Storm: The Hurricane Katrina Homeowners' Insurance Litigation, 4 BUS. L. BRIEF 49 (2007); David M. Stein, Flood of Litigation: Theories of Liability of Government Entities for Damages Resulting from Levee Breaches, 52 LOY. L. REV. 1335 (2006) (discussing early phases of In re Katrina Canal Breaches Consolidated Litigation); Symposium, The Problem of Multidistrict Litigation, 82 TuL. L. REV. 2423 (2008). 
Horizon.$^{20}$ Less obvious, however, from the Enbridge response and other recent cases, were the contributions that lawyers and legal scholars could make at other points within the disaster cycle, including the response phase. ${ }^{21}$ For lawyers, these roles include legal advisors and agency liaisons, operating within a management framework known as the Incident Command System (ICS).

ICS is a "management system designed to enable effective, efficient incident management by integrating a combination of facilities, equipment, personnel, procedures, and communications operating within a common organizational structure." ${ }^{, 2}$ Through the use of standardized positions (e.g., incident commander), common terminology (e.g., incident command post), and consistent management philosophies (e.g., unity of command), ICS seeks to facilitate the rapid integration of personnel from different agencies and entities into one organization to meet a common objective. ${ }^{23}$

Developed in California in the early $1970 \mathrm{~s},{ }^{24}$ the Incident Command System is used today throughout the United States by federal, state, tribal, and local governments, as well as nongovernmental organizations and the private sector, to plan for and respond to incidents of all kinds that require coordination among agencies and organizations. ${ }^{25}$ ICS applies to "all hazards," including natural disasters (e.g., tornadoes, earthquakes, hurricanes, floods) and manmade incidents (e.g., terrorist

20. See, e.g., John Wyeth Griggs, BP Gulf of Mexico Oil Spill, 32 EnERGY L.J. 57,58 n.2 (2011) (noting over 400 lawsuits were filed within the year following the blowout of the BP oil well). The lawsuits were in addition to claims presented directly to the BP Gulf Coast Compensation Facility, which transitioned on June 4, 2012, to the Court Supervised Settlement Program. For complete information, see DeEpwater Horizon Court-Supervised Settlement Program, www.deepwaterhorizonsettlements.com (last updated Jan. 11, 2013).

21. As Professor Farber recently observed, "although at first sight emergency response might seem like an area beyond the control of the legal system, legal scholarship has a clear capacity to help guide reforms." Farber, supra note 17, at 15.

22. U.S. DeP’'t of Homeland SeC., National Incident Management System 45 (2008) [hereinafter NIMS DOCUMENT], available at http://www.fema.gov/pdf/emergency/nims/ NIMS_core.pdf.

23. Id. In the Enbridge spill in Michigan, for example, response personnel came from agencies and organizations including the U.S. EPA, U.S. Coast Guard, U.S. Fish and Wildlife Service, the National Oceanic and Atmospheric Administration, National Transportation Safety Board, the U.S. Pipeline and Hazardous Material Safety Administration, the Michigan Department of Natural Resources and the Environment, the Michigan State Police, the Kalamazoo County Sheriff, the Calhoun County Public Health Department, the City of Battle Creek, Enbridge itself, plus contractors for the agencies and private parties. Jackson Statement, supra note 4; Enbridge Response, supra note 5 .

24. See Erik Auf der Heide, Disaster Response: Principles of Preparation and COORDINATION 135 (1989).

25. NIMS DOCUMENT, supra note 22 , at 89 . 
strikes, oil spills). ${ }^{26}$ Fire departments use ICS to put out fires, ${ }^{27}$ local law enforcement agencies use ICS to respond to traffic accidents and civil disorder, ${ }^{28}$ and public health officials use ICS to respond to public health emergencies. ${ }^{29}$ Court staff, school principals, and campus security use ICS to ensure the security of courthouses, ${ }^{30}$ school grounds, ${ }^{31}$ and college campuses. ${ }^{32}$ ICS can be used for planning events of all size, from local sporting matches ${ }^{33}$ to Olympic Games. ${ }^{34}$ It appears now that ICS is beginning to be adopted internationally. ${ }^{35}$

While ICS has existed for some forty years, the use of ICS grew significantly in the past decade because the United States learned hard lessons from infamous failures of incident management after 9/11 and

26. Robert RADVANOVSKy, CRITICAL InFRASTRUCTURE: HoMElAND SECURITY AND EMERGENCY PREPAREDNESS 100 (2006) (noting applications of ICS).

27. Firefighting Res. of Cal. Organized for Potential EMERgencies, InCident COMMAND SYSTEM FOR FIRE DEPARTMENT STRUCTURE FIRE OPERATIONS (ICS-SF) (1994).

28. See Cal. Emergency Mgmt. Agency, Law Enforcement Guide for Emergency Operations 18 (2009); see also GeOrge Buck, Preparing for TERrorism: An EMERgency SERviCes Guide 233-67 (1997) (describing response of the Los Angeles Police Department and other agencies to riots following the Rodney King verdict in 1992).

29. See, e.g., Peter D. Jacobson et al., The Role of Law in Public Health Preparedness: Opportunities and Challenges, 37 J. HEALTH POL. POL'Y \& L. 297, 312 (2012) (concluding that "there are serious deficiencies in legal preparedness that can undermine effective responses to public health emergencies").

30. Interview with Melissa Muir, Dir. Admin. Servs., U.S. Dist. Court, W. Dist. of Wash. (Feb. $1,2012)$ (explaining federal judges and court staff receive training in ICS).

31. See, e.g., Seattle Public Schools Policy No. 3432, at 1 (2011) (requiring "building principal to be certified on the incident command system"), available at http://www.seattleschools.org/modules/groups/homepagefiles/cms/1583136/File/Policies/Board/seri es3000/3432.pdf?sessionid=64795a4714bd9e2f77914afba79f915b.

32. See Oren R. Griffin, Constructing a Legal and Managerial Paradigm Applicable to the Modern-Day Safety and Security Challenge at Colleges and Universities, 54 ST. LOUIS U. L.J. 241, 246 (2009) (noting that in response to campus shootings and other safety incidents, the "higher education community should give careful consideration to the methods and management approaches, such as ICS, that attempt to improve coordination and effectiveness").

33. Michael D. Cardwell \& Patrick T. Cooney, Nationwide Application of the Incident Command System, FBI L. ENFORCEMENT BULL., Oct. 2000, at 10, 14, available at http://www.fbi.gov/stats-services/publications/law-enforcement-bulletin/2000-pdfs/oct00leb.pdf.

34. See, e.g., LynNe Genik \& David G. SMith, Command AND Control ANalysis of the South West Provincial Regional EMergency Operations Centre During Vancouver 2010 (2011), available at http://www.dodccrp.org/events/16th_iccrts_2011/presentations/049.pdf (describing use of ICS in planning and execution of 2010 Winter Olympics in Vancouver, British Columbia).

35. For example, the United States has helped train Brazilian security forces on ICS in preparation for the 2014 World Cup and the 2016 Olympics. See U.S. Sponsors Security Training with Rio de Janeiro Security Forces, DEP'T OF STATE, http://brazil.usembassy.gov/securityforcesrj.html (last visited June 9, 2013). FEMA has also provided ICS training internationally, including in Germany in fiscal year 2012 and Japan in 2013. See FEMA Emergency Management Institute, FED. EMERGENCY MgmT. AGENCY, http://training.fema.gov/EMI/ (last visited Apr. 20, 2013). 
Hurricane Katrina ${ }^{36}$ Use of ICS may also be growing simply because we have more frequent and catastrophic incidents, brought upon us by chronic problems including aging infrastructure, ${ }^{37}$ risky business endeavors, ${ }^{38}$ and climate change. ${ }^{39}$ Indeed, in the wake of more recent climate-related events including Hurricane Irene in 2011 and Hurricane Sandy in $2012,{ }^{40}$ policymakers and legal scholars ${ }^{41}$ may look increasingly to ICS as one tool for climate change adaptation. ${ }^{42}$ As such, ICS theory and practice must be understood by legal scholars and practitioners who seek to contribute to the growing fields of climate change adaptation and disaster response.

36. See, e.g., Eric Mayes, Local Disaster Preparedness Plan Evolving, About Response, PHILA. TRIB. (Sept. 11, 2011), http://www.phillytrib.com/newsarticles/item/468-local-disaster-preparednessplan-evolving-about-response.html (describing ICS as "[p]erhaps the most important change" in emergency management since $9 / 11$ ).

37. See, e.g., FARBER ET AL., supra note 16, at 64-68 (describing need to repair levees and dams throughout the United States); Bobby Magill, How Much Life Is Left in the Trans-Alaska Pipeline?, Popular Mechs., Feb. 2012 (recognizing the Trans-Alaska Pipeline is thirty-five years old and in need of investment to extend useful life).

38. Professor Oliver Houck describes the Deepwater Horizon disaster as a demonstration of "risk creep," where on-shore oil drilling more than a century ago moved into wetlands, then open water, then finally water a mile deep. Oliver A. Houck, Worst Case and the Deepwater Horizon Blowout: There Ought to Be a Law, 40 ENVTL. L. REP. 11033, 11034 (2010).

39. For more than twenty years, the predicted effects of climate change have included disasters such as stronger and more frequent hurricanes. See, e.g., BILL MCKIBBEN, THE END OF NATURE 9596 (1989). Over time, these predicted effects, which also include more intense and frequent fires, floods, droughts, storms and tornadoes, have become increasingly sophisticated and certain. See Chris Wold, David Hunter \& Melissa Powers, Climate Change and the LaW 22 (2009). Recent U.S. history appears to have validated these predictions, with record floods, fires, hurricanes, and heat waves in 2011 and 2012. See sources cited infra notes 277-89 and accompanying text.

40. Of course, one cannot say with certainty that recent hurricanes including Irene and Sandy were caused directly by climate change. However, the hurricanes were likely strengthened by climate change, through such effects as the rise in sea level and warmer waters in the Atlantic. See Jeffrey Thaler, Fiddling as the World Floods and Burns: How Climate Change Urgently Requires a Paradigm Shift in the Permitting of Renewable Energy Resources, 42 ENVTL. L. 1101, 1115 n.63 (2012).

41. See, e.g., Victor B. Flatt, Domestic Disaster Preparedness and Response, in THE LAW OF Adaptation to Climate Change 481 (Michael B. Gerrard \& Katrina Fischer Kuh eds., 2012) (observing that "the issue of disaster preparedness and response has much to do with climate change adaptation").

42. According to the EPA, climate "adaptation" refers to "efforts by society or ecosystems to prepare for or adjust to future climate change." See Adaptation Overview, ENVTL. PROT. AGENCY, http://www.epa.gov/climatechange/impacts-adaptation/adapt-overview.html (last visited Feb. 20, 2013). Consistent with the predictions for climate change impacts, organizations including the Intergovernmental Panel on Climate Change and agencies including the EPA have emphasized the need for climate change adaptation plans to help prepare for the anticipated impacts of climate change. See, e.g., InTERGOVERnMENTAL Plan On Climate Change, Fourth ASSESSMENT REPORT (2007). One "guiding principle" for the development of such plans, according to the EPA, is to "use strategies that complement or directly support other related climate or environmental initiatives, such as efforts to improve disaster preparedness." EnVtL. Prot. AgEnCy, Climate CHANGe AdAPTATion PLAN 33 (2012). One such effort to improve disaster preparedness is expanded training on ICS. 
Filling a gap in the legal literature, Part II will provide lawyers and legal scholars with an introduction to the Incident Command System, outlining the origin, doctrines, and organizational framework of ICS, along with major early critiques. Part III illustrates the law and application of ICS through transformative events including 9/11, Hurricane Katrina, and the Deepwater Horizon. Part IV examines the potential roles for lawyers in ICS, including the emerging ICS position of legal officer. Part V concludes with suggestions for future legal research and practice in the Incident Command System.

\section{INTRODUCTION TO THE INCIDENT COMMAND SYSTEM}

Although some forty years old, the Incident Command System seems to have largely escaped the critical attention of the legal community. ${ }^{43}$ This may be changing, however, because legal scholars ${ }^{44}$ and practitioners ${ }^{45}$ are coming to recognize the new reality brought to us by aging infrastructure, risky endeavors, and climate change, a reality summed up

43. One notable exception is Professor William Nicholson, who has been writing about the Incident Command System from the perspective of emergency management and homeland security for over a decade. See, e.g., Nicholson, supra note 17; William C. Nicholson, Legal Issues in Emergency Response to Terrorism Incidents Involving Hazardous Materials: The Hazardous Waste Operations and Emergency Response ("HAZWOPER") Standard, Standard Operating Procedures, Mutual Aid and the Incident Management System, 9 WIDENER L. SYMP. J. 295 (2003) [hereinafter Nicholson, Legal Issues in Emergency Response]; William C. Nicholson, Seeking Consensus on Homeland Security Standards: Adopting the National Response Plan and the National Incident Management System, 12 WIDENER L. REV. 491 (2006) [hereinafter Nicholson, Seeking Consensus].

44. Among the legal scholarship, a number of scholars have acknowledged the Incident Command System. See, e.g., FARBER ET AL., supra note 16, at 136-45 (discussing ICS in context of the National Incident Management System); Denis Binder, Lessons from the BP Emergency Action Plan in Action, 40 ENVTL. L. REP. 11115, 11116 (2011) (discussing critical elements of an emergency action plan, including provisions for a "unified incident command and incident commander"); Lance Gable, Evading Emergency: Strengthening Emergency Responses Through Integrated Pluralistic Governance, 91 OR. L. REV. 375, 410 (2012) (identifying ICS as the "backbone" of most current public health response plans, consistent with traditional governance models); Gregg P. Macey, Environmental Crisis and the Paradox of Planning, 2011 BYU L. REV. 2063. Professor Macey's article probably goes furthest in acknowledging the existence and need for organizing systems such as the Incident Command System, recognizing that "what stands between us and the scale and scope of future environmental crises are organizations." Macey, supra, at 2066. After examining the roots of organizational challenges and failures in the context of the Deepwater Horizon response, Macey concludes that the "struggle to differentiate tasks and subunits and then piece them together during moments of great uncertainty ... should receive greater attention." Id. at 2111.

45. Practitioners have also recognized ICS in recent work. See, e.g., Otto J. HetZel \& ERNEST B. ABBotT, HOMELAND SECURITY AND EMERGENCY MANAGEMENT: A LEGAL GUIDE FOR STATE AND LOCAL GOVERNMENTS $252-53$ (2d ed. 2010) ("ICS permits the authority having jurisdiction over the incident to retain command and control, while accessing the resources of local, state, and federal agencies through mutual aid and other mechanisms."); Joseph V. Panesko, Are You Prepared? Lawyers' Roles in Preparing for and Responding to Disasters, WASH. ST. BAR Ass'N BAR NEWS, Jan. 2008, at 16 ("[A]ll levels of government emergency responders, whether local, state, or federal, are required to implement the ICS template into their operational structures ...."). 
succinctly by Professor Farber: "Disasters, both natural and humaninduced, are an increasingly common feature of twenty-first century life." 46 This reality gives rise to a "dire need for a systematic, thoughtful

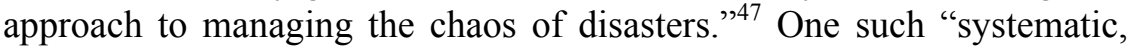
thoughtful approach" may be the Incident Command System. Understanding ICS today may require some knowledge of how it developed. This Part thus begins by discussing the origin of ICS. For the convenience of readers new to the Incident Command System, this Part then outlines the basic structure and tenets of ICS, along with some critical evaluations of ICS theory.

\section{A. Origins}

The Incident Command System arose in response to a series of devastating wildland fires in southern California in the fall of 1970. Within thirteen days, the fires consumed sixteen lives, 700 structures, and over one-half million acres, with costs and losses totaling \$18 million per day. ${ }^{48}$ While the various fire agencies did their best to contain the conflagrations, differences in personnel, equipment, terminology, and organizational structures hampered the effectiveness of their response efforts. ${ }^{49}$ In 1972, Congress tried to help address those problems by providing funds to the U.S. Forest Service for research on methods to "strengthen fire command and control systems." ${ }^{, 00}$ That research, drawing upon Forest Service collaborations with local fire agencies in southern California, resulted in a system that came to be known as FIRESCOPE (Firefighting Resources of California Organized for Potential Emergencies). ${ }^{51}$

In 1973, a FIRESCOPE technical team assembled to guide development of a command structure that would facilitate multi-agency coor-

46. Farber, supra note 17, at 20.

47. Id.

48. RADVANOVSKY, supra note 26, at 97.

49. One account described the California wildfires of 1970 as a scene of "total chaos that enveloped the dozens of emergency services agencies that responded to these fast moving, erratic wildfires." Fire engines from the northern part of the state were sent south, passing engines on Interstate 5 from the south moving north, each deployed to fires hundreds of miles from their respective bases. DANA Cole, The InCident Command System: A 25-YeAr Evaluation by California PRACTITIONERS 209 (2000).

50. Department of the Interior and Related Agencies Appropriations Act, Pub. L. No. 92-369 (1972); see SENATE Subcomm. ON APPROPRIATIONS FOR THE DEP'T OF THE INTERIOR \& RELATED AGENCIES, 92d Cong. 2d Sess. at 1734 (Mar. 7, 1972) (appropriating \$900,000 for research at Riverside, California, and Fort Collins, Colorado).

51. See sources cited supra note 50. For a detailed history of FIRESCOPE and its continuing role in California fire and emergency response, see FIRESCOPE, www.firescope.org (last visited Apr. 20, 2013). 
dination in responding to emergency incidents. ${ }^{52}$ In developing this command structure, technical team members drew organizational ideas from contemporary research on systems theory ${ }^{53}$ and operational structures from existing models for fire response. ${ }^{54}$ Reflecting growing interest in a command structure that could apply to all types of emergencies, the focus expanded beyond firefighting, and the "Incident Command System" was born. ${ }^{55}$

By the mid-1970s, the FIRESCOPE agencies had agreed upon the major features and terminology of the Incident Command System and, by 1980, had successfully tested ICS on several major wildland fires. ICS was soon being used widely on fires throughout southern California, and it was then considered for use nationally on a much broader array of emergencies, including floods, earthquakes, airplane crashes, and hazardous materials incidents. ${ }^{56}$ In 1994, ICS received one of its first tests in a major disaster when applied in response to the Northridge Earthquake in Los Angeles. ${ }^{57}$ Over time, the experiences of different organizations implementing ICS in different settings led to the development of differ-

52. RADVANOVSKY, supra note 26 , at 97.

53. COLE, supra note 49, at 209. Systems theorists "see common principles in the structure and operation" of systems and seek to improve systems through doctrines including the use of a common language to enable interdisciplinary collaborations. LARS SKYTTNER, GENERAL SYSTEMS THEORY: AN INTRODUCTION 275 (1996). Systems theory enjoyed particular popularity in the early 1970s. See, e.g., Robert M. Pirsig, Zen AND the ART OF Motorcycle MaintenanCe 101-02 (1974) (exploring philosophical meditation on systems including governments, churches, and motorcycles). In 1972, establishing the research program that would lead to the creation of the Incident Command System, Congress appeared to have systems theory distinctly in mind when it provided funding for "systems research" at Riverside, California. See CoLE, supra note 49. Reconnecting ICS to systems theory thirty years later, Cole observes that the "Incident Command System may well be considered one of the longest-running experiments in applied systems thinking." Id. at 211.

54. Telephone Interview with Chuck Mills, Emergency Mgmt. Sys., Inc. (Apr. 22, 2012) [hereinafter Mills Interview]. Mr. Mills served as a member of the FIRESCOPE technical team that developed ICS, and as of this writing, remains actively engaged in ICS training and assistance as a private consultant. Models for operational structure drew from existing fire response systems including the Fireground Command System developed by the Phoenix Fire Department. Id. For more on the Fireground Command System, see Alan V. BRunacini, Fire Command (1985).

55. Mills Interview, supra note 54.

56. RADVANOVSKY, supra note 26, at 98.

57. Dick A. Buck, Joseph E. Trainor \& Benigno E. Aguirre, A Critical Evaluation of the Incident Command System and NIMS, 3 J. Homeland SEC. \& EMERGENCY MgMT. 1, 2 (2006). 
ent versions of ICS,${ }^{58}$ leading to some initial confusion over which "ICS" model an individual organization should follow. ${ }^{59}$

\section{B. ICS Overview}

Today, while many versions of ICS exist, there is one national standard for ICS, incorporated within the National Incident Management System (NIMS) ${ }^{60}$ and published by the U.S. Department of Homeland Security. Individual agencies may publish their own ICS guides ${ }^{61}$ but they must be "NIMS-compliant." ${ }^{62}$ Private organizations or authors may also publish their own ICS guides. ${ }^{63}$ For a wealth of information and materials on ICS, the Federal Emergency Management Agency (FEMA) maintains an online ICS Resource Center. ${ }^{64}$ For the convenience of legal scholars and practitioners, this section provides an overview of the basic doctrines and structures of the Incident Command System as described in the National Incident Management System. ${ }^{65}$

58. Different versions of ICS include "Hospital ICS," see CAL. EMERGENCY MED. SeRvs. Auth., Hospital InCIDENT COMMAND SYSTEM Guidebook (2006), and "Law Enforcement ICS," see CAL. EMERgency Mgmt. Agency, LaW Enforcement Guide For EMERgENCy Operations (2009). For additional information, see WALTER G. GREEN III, COMMAND AND CONTROL OF DISASTER OPERATIONS 9 (2001) (noting different ICS versions developed by organizations including the National Wildfire Coordinating Group, the National Fire Academy, and the American Society for Testing and Materials).

59. See Glenn E. Brautaset, Incident Management Teams: A Feasibility Study for SKAGIT COUNTY 9 (1994), available at http://www.usfa.fema.gov/pdf/efop/efo37796.pdf (noting confusion between FIRESCOPE ICS and NIIMS ICS).

60. NIMS DOCUMENT, supra note 22, at 89.

61. See, e.g., Envtl. Prot. Agency, Incident Management Handbook: Incident COMMAND SYSTEM (2007) [hereinafter EPA ICS HANDBOOK].

62. In an evident attempt to address common confusion on this point, FEMA published on its website the following Frequently Asked Question:

Q: In order to meet NIMS compliance, does it matter which brand of ICS is used. . . ?

A: To be NIMS compliant, you need to use the Incident Command System (ICS) structure described in the current version of NIMS.

Incident Command System, FeD. EMERGENCY MGMt. AgENCY, http://www.fema.gov/emergency/ nims/IncidentCommandSystem.shtm (last visited Apr. 20, 2013) (emphasis omitted).

63. See, e.g., Tim Deal, Chuck Mills \& Mike Deal, All Hazard Field Guide: A RESPONDER'S HANDBOOK USING THE NATIONAL INCIDENT MANAGEMENT SYSTEM'S INCIDENT COMMAND SYSTEM (2011)

64. See ICS Resource Center, Fed. EMERGENCy MGMT. AGENCy, http://training.fema.gov/EMIWeb/IS/ICSResource/index.htm (last visited Apr. 20, 2013).

65. Note that the brief outline of ICS provided for convenience in this Part should not be regarded as a substitute for proper training in ICS as may be required for compliance with NIMS. For information on NIMS-compliant ICS training opportunities, see Welcome to the National Preparedness Directorate National Training and Education, Fed. EMERgEnCy Mgmt. Agency, www.training.fema.gov (last visited Apr. 20, 2013). 


\section{Organizational Structure}

The basic organizational structure of the Incident Command System appears below in Figure 1. ICS terminology and organizational principles draw from classical theory in military operations ${ }^{66}$ and business management. ${ }^{67}$ Consistent with military doctrine, ${ }^{68}$ ICS is intended to be flexible and scalable, ${ }^{69}$ so that the size and complexity of a particular ICS organization will depend upon the size and complexity of a particular incident. ${ }^{70}$ Where multiple individuals are required to support an ICS function, ICS doctrine requires maintaining an appropriate "span of control"71 to ensure effective command throughout the ICS organization. This scenario may require adding deputies, or expanding an organization to include additional organizational levels or units, ${ }^{72}$ each with their own designated supervisors. To ensure clarity in the chain of command, the ICS principle of "unity of command" requires that each individual within an ICS organization report to one, and only one, supervisor. ${ }^{73}$

66. See infra note 85 and accompanying text (general staff system).

67. Buck, supra note 57, at 1.

68. $C f$. Headquarters, Dep't of the Army, Commander and Staff OfFicer Guide 2-3 (2011) [hereinafter COMMANDER AND STAFF OFFICER GUIDE] ("The mission determines which activities to accomplish. These activities determine how commanders organize, tailor, or adapt their individual staffs to accomplish the mission. The mission also determines the size and composition of a staff to include staff augmentation.").

69. See NIMS DOCUMENT, supra note 22, at 6.

70. BUCK, supra note 28. For example, if a certain incident does not require a public information officer, the ICS structure for that incident will not include one. If, on the other hand, a major incident requires significant production and dissemination of public information, then the public information officer (PIO) may be assisted by a Deputy PIO and a team of assistants.

71. Under NIMS, an appropriate span of control between supervisors and individuals is defined as a ratio between 1:3 and 1:7, with 1:5 being optimal. NIMS DoCUMENT, supra note 22, at 47, 147 . Of course, span of control, along with many other elements of ICS, was not invented for purposes of ICS, but borrowed from other sources including business management. See, e.g., NAT'L INDUS. Conference BD., The Chief Executive And His Job: Studies in Personnel Policy, no. 214, at 15 (1968) (noting studies of span of control in U.S. and foreign companies, finding that roughly half the companies had between four and seven direct reports to the CEO).

72. NIMS DOCUMENT, supra note 22, at 91. Radvanovsky observed in his 2006 textbook, "One of the greatest strengths of ICS is the ability to expand or contract the organization as needed to fit the activity level at the incident. Deputies may be added as needed to maintain span of control, sections may be subdivided, and the organization can grow to include other agencies and jurisdictions as needed." RADVANOVSKY, supra note 26 , at 110.

73. NIMS DOCUMENT, supra note 22 , at 149 . Of course, this principle considerably predates development of the Incident Command System. Cf. Matthew 6:24 ("No one can serve two masters."). 
Figure 1: ICS Structure

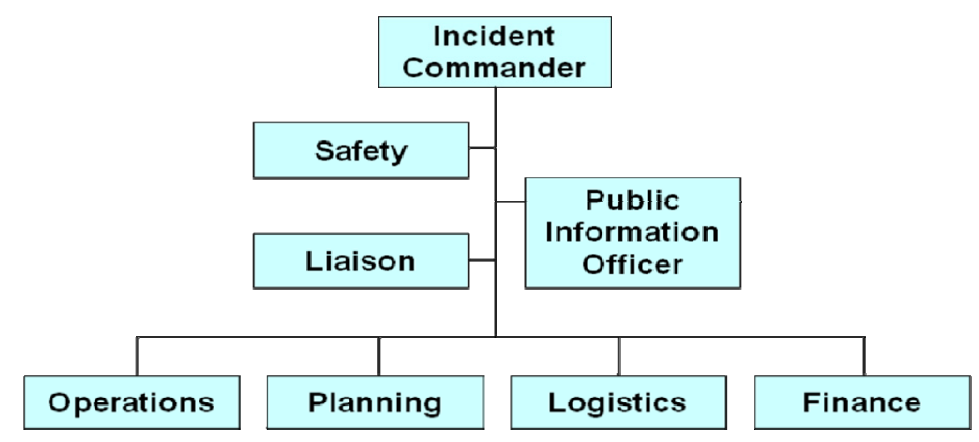

2. Organizational Components

\section{a. Incident Command}

The ICS structure builds from the top down, beginning with the incident commander. ${ }^{74}$ As an ICS organization expands or contracts, the incident commander maintains overall responsibility for managing the incident. Where a single incident may involve the jurisdiction and responsibilities of two or more agencies or organizations, two or more incident commanders may be designated to work together as "unified command." Together, unified command supports the ICS principle of "management by objectives" tives and strategies. ${ }^{76}$ At the same time, each organization maintains its authority, responsibility, and accountability. ${ }^{77}$ Where one large incident or multiple related incidents require establishing multiple ICS structures, an "area command" may be established to facilitate overall incident coordination without engaging in direct operational support. ${ }^{78}$

\section{b. Command Staff}

The ICS command staff typically includes a safety officer, liaison officer, and public information officer, who report directly to the incident commander or unified command..$^{79}$ Command staff may also include other officers, as needed for an individual incident. ${ }^{80}$ The safety officer

74. NIMS DOCUMENT, supra note 22, at 91.

75. See id. at 47.

76. See generally id. at 49, 149 (defining "Unified Command").

77. See id. at 50.

78. Id. at 115-17, 135 (defining “Area Command”).

79. Id. at $92,137$.

80. Additional command staff may include a medical officer or a legal officer. See id. at 95; see also sources cited infra notes 355-95 and accompanying text (discussing the legal officer). In 
monitors all ICS operations and advises incident commanders on all matters related to health and safety of responders. The safety officer also has authority to stop or prevent unsafe actions during incident operations. ${ }^{81}$ The liaison officer facilitates coordination with all agencies, nongovernmental organizations, and private sector parties that have some interest in the incident without having legal authority over the incident. These assisting or cooperating organizations may appoint representatives to the liaison officer to ensure effective coordination. ${ }^{82}$ The public information officer is responsible for communicating with the public, news media, and other agencies to provide timely and accurate information about the incident. For large incidents, the public information officer and assistants may establish a "joint information center" for ease of disseminating information. ${ }^{83}$

\section{c. General Staff}

Consistent with classical military organization, ${ }^{84}$ the ICS general staff includes the section chiefs for operations, planning, logistics, and finance and administration, plus other major ICS functions, as needed. ${ }^{85}$ The operations section is responsible for developing tactics and carrying out actions in order to achieve the incident objectives. ${ }^{86}$ The planning section is responsible for collecting, evaluating, and disseminating operational information. ${ }^{87}$ The planning section also prepares an incident action plan to guide the response and continues to update it as necessary

military doctrine, the legal officer is a required component of the command staff. Military doctrine also requires appointment of an inspector general and a chaplain, see COMMANDER AND STAFF OFFICER GUIDE, supra note 68 , at $2-3$, positions that have yet to be prescribed for an ICS organization.

81. NIMS DOCUMENT, supra note 22, at 52.

82. Id.

83. Id.

84. Military historians report that the general staff system employed by the military today dates back more than two centuries, to around 1809 when it was invented by the Prussian army after its defeat by Napoleon. This system was later adopted by the U.S. military in 1903. The system organized needs by functional areas including plans, operations, logistics, administration, and intelligence, Robert Greenhalgh Albion, Introduction to Military History 140-41 (1929), which almost precisely reflects the functional structure of the modern Incident Command System. For the modern military equivalent, see, for example, COMMAND AND STAFF OFFICER GuIDE, supra note 68 , at $2-5$ (noting the "coordinating staff" supporting functions include plans, operations, logistics, and intelligence).

85. NIMS DOCUMENT, supra note 22 , at 54 . One optional functional area explicitly identified by ICS is intelligence and investigations. Id. at 91 .

86. See generally id. at 97 (Tab 2 - The Operations Section).

87. Id. at 105 . To carry out these responsibilities, the planning section may be assisted by any number of technical specialists, including experts in meteorology, epidemiology, law, cultural resources, and hazardous materials. 
throughout the incident. ${ }^{88}$ The logistics section provides and manages all support needed for an incident response. This includes ordering and tracking all necessary personnel and equipment and ensuring food, fuel, medical services, and facilities needed to support response personnel. ${ }^{89}$ ICS facilities supported by logistics typically include an incident command post for the incident commander or unified command and base camps for housing personnel. ${ }^{90}$ The finance and administration section manages funding, monitors expenditures, and ensures compliance with procedures for procurement, compensation, and claims related to the incident response. $^{91}$

\section{Critiques of the Incident Command System}

Given the decades of experience with implementing the Incident Command System across the country, social scientists and emergency responders naturally have undertaken critical evaluations of ICS. One consistent observation throughout these studies is that practitioners almost invariably express support for the Incident Command System. ${ }^{92}$ This broad, consistent support for ICS among practitioners may result from factors with varying rationales. One suspect factor may be the phenomenon that social psychologists describe as system justification theory, which observes a general human tendency to support and defend a social status quo, regardless of whether this support is warranted by a rational consideration of the evidence. ${ }^{93}$ One more meritorious factor

88. Typically, the incident action plan will be updated continuously throughout the response for each operational period, generally twelve or twenty-four hours. In this way, the IAP can continually reflect changing conditions, new objectives, and lessons learned. RADVANOVSKY, supra note 26, at 108 .

89. See generally NIMS DocumENT, supra note 22, at 107 (Tab 4 - The Logistics Section).

90. For more on ICP facilities, see $i d$. at 119 (Tab 7 - Facilities and Locations).

91. See generally id. at 113 (Tab 5 - The Finance / Administration Section). Because of these administrative functions, the finance section may be situated at the incident scene or may operate remotely wherever an organization's finance and administration units would normally function.

92. See, e.g., Buck, supra note 57, at 3 ("The response community has been almost universal in its praise of ICS," citing several studies between 1986 and 2001); COLE, supra note 49, at 207 ("[T]he consensus among long-time practitioners seems to be that "ICS works."”). This is not, of course, to claim there is no grumbling about ICS among incident commanders and first responders. See, e.g., Cynthia Renaud, The Missing Piece of NIMS: Teaching Incident Commanders How to Function at the Edge of Chaos, HomelAND SEC. AFF., June 2012, at 3, available at $\mathrm{http}: / /$ www.hsaj.org/?article=8.1.8\&fromemail=2 (noting that "many in the first-responder community complain that NIMS doesn't work" because ICS bureaucracy cannot adequately prepare responders for initial engagement in chaotic environments).

93. For an introduction to system justification theory in the context of law and lawyering, see Gary Blasi \& John T. Jost, System Justification Theory and Research: Implications for Law, Legal Advocacy, and Social Justice, 94 CAL. L. REV. 1119 (2006). For a powerful illustration of system justification in the wake of Hurricane Katrina, where hurricane victims were widely blamed for their 
may be the substantial investment that many practitioners have in ICS, accumulated through years of training and deployments, contributing to their readiness to respond to the next disaster. Yet another factor contributing to widespread support for ICS among practitioners may simply be the lack of any serious alternative to ICS within the last forty years.

Supporters of ICS may submit that ICS has stood the test of time and has withstood the scrutiny of numerous critical studies. Early critiques of ICS appeared to mistake failures of ICS implementation for defects in ICS design. ${ }^{94}$ Failures reflecting human error will always challenge any social organization, of course, but such failures also suggest relatively modest remedies such as training and experience, rather than invention and deployment of whole new systems. Other critical evaluations of ICS, however, deserve closer consideration to discern both the appropriate uses of ICS and perhaps its limitations. Three leading studies on ICS will be considered in turn below.

\section{Cole (2000)}

In 2000, Dana Cole of the California Department of Forestry and Fire Protection published the results of a study evaluating twenty-five years of practice with ICS in California. ${ }^{95}$ In view of this quarter century of experience, Cole begins with the overall conclusion that " $[\mathrm{w}]$ hile not perfect, ICS is a proven structure for making people productive in working together to accomplish critical tasks during times of crisis." ${ }^{96}$ However, reviewing the literature on ICS to that point, Cole noted a number of common criticisms of ICS. While ICS evidently worked well for fire incidents, Cole noted suggestions that it failed to accommodate non-fire entities into the ICS structure, in particular failing to integrate law enforcement and volunteers. Cole also noted concerns regarding the "considerable differences in how [ICS] is implemented from one agency to another." Cole further acknowledged concerns with "mobilization over-

own suffering, see Jaime L. Napier et al., System Justification in Responding to the Poor and Displaced in the Aftermath of Hurricane Katrina, 6 ANALYSES SOC. ISSUES \& PUB. POL'Y 57 (2006).

94. Early critics suggested, for example, that ICS was weak in promoting interagency coordination, allowing for separate command posts for fire and law enforcement organizations. Buck, supra note 57 , at 4 . Separate command posts could, in fact, severely hinder interagency coordination, as seen with the 9/11 response at the World Trade Centers. However, practitioners pointed out that ICS was explicitly designed to promote interagency coordination, and that features such as separate command posts for different agencies conflicted with ICS concepts such as unified command and practices recommended for achieving unified command. See, e.g., GREEN, supra note 58, at 10 ("The most successful approach to unified command under these conditions appears to include ... one Command Post.").

95. COLE, supra note 49.

96. Id. at 233 . 
kill," an idea that ICS may lead to "serious problems of convergence and congestion at the disaster site."

To evaluate these and other criticisms, Cole conducted a statistical survey of experienced practitioners of ICS within the California fire services. ${ }^{98}$ Asked to evaluate the relative strength or weakness of ICS according to sixteen attributes, ${ }^{99}$ respondents statistically identified no weaknesses among the sixteen listed attributes, and they had a strong tendency toward unanimity among the highest rated attributes. Not surprisingly, the ICS attributes with the highest mean ratings, including "Predefined hierarchy," "Uniform terminology," "Incident Action Plan," and "Span-of-Control," reflect some of the most fundamental features of ICS and align with internal applications of ICS within a given response community. ${ }^{100}$ The Cole study also found that the lowest rated attributes of ICS, including "Resource mobilization," "Effectiveness of integrating non-government organizations," and "Consistency of implementation among various agencies," reflected external applications where ICS comprehension and social relationships among responders may be most likely lacking.

From this statistical evaluation, Cole posits "the single biggest threat to the effective use of ICS: external misalignment."101 The challenge then, as Cole sees it, is one of expanding the community of individuals and organizations familiar with ICS, assisted by standardizing the ICS model while at the same time allowing for continual feedback and improvement. To meet these challenges, Cole emphasizes the need for expansive training and practice in ICS. ${ }^{102}$ Cole also makes three systemic recommendations: (1) "Establish a multi-disciplinary national systems management process to ensure the integrity and consistency of implementation of ICS"; (2) "Develop a strategy for promoting ICS as the standardized model for emergency incident management"; and (3) "Institutionalize an ongoing systems evaluation process."103

97. Id. at 212-13.

98. The 122 respondents to this questionnaire had an average of 26.6 years of experience with fire service and 17.7 years with using ICS. Id. at 215.

99. Respondents rated each attribute individually on a scale from one (maximum weakness) to ten (maximum strength), without regard to ranking attributes against each other. Id.

100. Id. at $218-19$.

101. Id. at 223. By "external misalignment," Cole appears to mean failures to comprehend and implement ICS properly by parties that Cole describes as "uninitiated external entities," namely, parties unfamiliar with ICS doctrine and practice. Id. at 224.

102. Cole notes in particular the need for meaningful practice, making the following observations: "Imagine trying to build a great theater ensemble or a great symphony orchestra without rehearsal. Imagine a championship sports team without practice. In fact, the process by which such teams learn is through continual movement between practice and performance." Id. at 223.

103. Id. at 224-25. 
In fact, since the Cole (2000) study, all three of these recommendations appear to have been embraced through the 2004 publication of the National Incident Management System, as will be explained in Part III.

\section{Bigley and Roberts (2001)}

In 2001, social scientists Gregory Bigley and Karlene Roberts, respectively from the University of Washington and the University of California, undertook a critical study of ICS from the perspective of reliability, which they submit "is becoming a vital organizational quality or competency." 104 Drawing from data collected systematically through interviews with personnel from a large county fire department in California, Bigley and Roberts conclude that "ICS-based organizations may perform more reliably under extreme conditions than organizations founded on alternative approaches." 105 Bigley and Roberts suggest that this reliability derives from "three main ICS factors-structuring mechanisms, organizational support for constrained improvisation, and cognition management methods." 106

By "structuring mechanisms," Bigley and Roberts refer to the features of ICS that allow for rapidly developing and altering organizational structures to meet the specific and changing needs of an individual incident. ${ }^{107}$ These features include the flexible structure of ICS that allows for building an ICS organization from the top down, beginning with the incident commander and including only those components needed to meet incident objectives. ${ }^{108}$ On this point, data collected by Bigley and Roberts confirmed the concern reported by Cole about the threat of organizational "overkill," agreeing that "overdevelopment of higher-level components, such as sections, branches, and divisions, can compromise system effectiveness." ${ }^{109}$ Such excessive development, in the words of

104. Gregory A. Bigley \& Karlene H. Roberts, The Incident Command System: HighReliability Organizing for Complex and Volatile Task Environments, 44 ACAD. MGMT. J. 1281 (2001). Bigley and Roberts define "reliability" to mean "the capacity to continuously and effectively manage working conditions, even those that fluctuate widely and are extremely hazardous and unpredictable." Id.

105. Id. at $1281-82$.

106. Id. at 1282 .

107. Id. at 1286. Confirming this connection between structure and reliability, Peter Senge has observed that, for good or ill, "structure influences behavior." Peter M. SENGe, The FifTH Discipline: The ART AND PRACTICE OF the Learning ORganization 42 (1990). "The systems perspective tells us that we must look beyond individual mistakes or bad luck to understand important problems. We must look beyond personalities and events. We must look into the underlying structures which shape individual actions and create the conditions where types of events become likely." Id. at 42-43 (emphasis added).

108. For example, beyond the incident commander, most fires were reported to require ICS activation only for the operations section. Bigley \& Roberts, supra note 104, at 1287.

109. Bigley and Roberts illustrated this concern with a colorful quote from one battalion chief: 
one battalion chief quoted by Bigley and Roberts, is "not using the incident command system as designed." 110

Another ICS factor contributing to the high reliability identified by Bigley and Roberts is "organizational support for constrained improvisation." 111 By this, Bigley and Roberts recognize that complex and dynamic systems are never fully comprehensible by any one member of an organization. As such, all supervisors, including the incident commander, must allow subordinates a degree of latitude to improvise. ${ }^{112}$ Improvisation may mean creative use of a set of tools, as with the available equipment on a fire truck, or it may mean a form of breaking the rules, varying from routine or standard operating procedures. ${ }^{113}$ However, for purposes of reliability, Bigley and Roberts note that improvisation must be constrained within certain limits. Within the ICS context, for example, improvisation will not tolerate "freelancing," the conduct by individuals or organizations acting wholly outside of the ICS command structure. ${ }^{114}$

A final ICS factor contributing to high reliability is what Bigley and Roberts call "cognition management methods." 115 These are methods by which any individual member of an organization builds and maintains a viable understanding of the system to which they belong. Maintaining this understanding can be particularly challenging in many ICS contexts such as emergencies and disasters, where the rapidly changing needs of the incident are accompanied by adjustments in organizational structures. As Bigley and Roberts observed, ICS helps individuals meet these cognitive challenges through a series of mechanisms, including a clear set of incident objectives and defined roles within the ICS structure to help maintain mental focus and avoid "cognitive overload."

I'll tell you where it doesn't work. . . . You get some people in the incident command system, the first thing they start doing is they start filling in bodies in all the boxes. "I'm the incident commander. I need operations, plans. . . . I'll just fill in the boxes." And there's nobody left to put out the fire.

Id. at 1287 .

110. Id.

111. Id. at 1286 .

112. Concurring with Bigley and Roberts on the key role of improvisation, another researcher elaborated, "The discipline provided by the ICS and the improvisation required by a problemsolving, open-system response are often assumed to be opposite ends of a linear scale. Recent experience . . . , however, suggests that these are not opposites, that agility and discipline can both be achieved." John R. Harrald, Agility and Discipline: Critical Success Factors for Disaster Response, 604 Annals Am. ACAD. POL. \& Soc. SCI. 256, 267 (2006) (citing studies of successful improvisation and creativity in the $9 / 11$ responses at the World Trade Centers and Pentagon).

113. Bigley \& Roberts, supra note 104, at 1289.

114. Id. at 1290 (explaining how freelancing on a structural fire can lead to fatal consequences for firefighters).

115. $I d$.

116. Id. at 1295. As one example of managing cognitive demands, Bigley and Roberts cite comments from one firefighter, who in the face of a structural fire may be thinking about running 
Bigley and Roberts concluded that investing in ICS capacity "seems imperative for the growing number of organizations facing an expanding number of catastrophic scenarios." "At the same time, the study recognized that additional research was needed to ascertain the degree to which ICS could succeed in cases where participants did not share clearly defined values and organizational interests. ${ }^{118}$

\section{Buck et al. (2006)}

In 2006, researchers from the University of Delaware published what may be the most comprehensive evaluation of the Incident Command System as a tool for managing disaster response activities in the United States. ${ }^{119}$ As compared with Cole (2000) and Bigley and Roberts (2001), Buck et al. (2006) expressed more reserved support for ICS, suggesting that the relative success of ICS may depend on the specific characteristics of an incident, the location where it is used, and the organizations who may be called upon to use it.

Synthesizing from an expansive review of the literature, as well as from primary data collected from members of FEMA's Urban Search and Rescue teams, Buck et al. identify several factors that they suggest predict an effective use of ICS. The first factor may be a type of incident where responders operate with established tactics, including technical aspects of ICS. Buck et al. cite the response by the Oklahoma City Fire Department to the 1995 bombing of the Murrah Federal Building as a case where ICS "worked effectively," in part because the "command staff was well trained in ICS." ${ }^{120}$ As a second factor predicting ICS success, Buck et al. suggest that responders should have a "shared vision of the response through planning, practice, and experience."121 An example given here was the ICS response to the bombing at the 1996 Summer Olympics in Atlanta, for which responding agencies, including the FBI and the Georgia Bureau of Investigations, had specifically practiced months in advance. ${ }^{122}$ A third factor predicting ICS success for Buck et al. is a response community, one characterized by a common language, common purposes, and personal ties developed over time through shared

low on fuel in a chainsaw, while at the same time the truck captain is anticipating needs for additional manpower. Id. at 1292.

117. Id. at 1297 .

118. Id. at 1295-96. Such cases may include, for example, oil spills, where the ICS organization may encompass both government regulators and a responsible party. See discussion infra Part III.D.

119. Buck, supra note 57 , at 1 .

120. Id. at 7.

121. Id. at 12 .

122. Id. 
experiences. For Buck et al., the ICS response to the Northridge Earthquake in 1994 succeeded "because the local responders were part of a greater Los Angeles response community . . . nurtured over a number of years by the California Office of Emergency Services."123

While identifying factors that predict ICS success, Buck et al. also suggest conditions where ICS deployments might prove more challenging. These include incidents where boundaries are diffuse, defying efforts to establish perimeter control. One example offered here was the uncoordinated response to the 2003 crash of the space shuttle Columbia, which disintegrated over Texas and Louisiana upon re-entry to Earth's atmosphere. In the response to that incident, no central control appeared over the collection of shuttle debris by local residents for at least the first few days, hampering the accident investigation. ${ }^{124}$ Similarly, according to Buck et al., ${ }^{125}$ ICS responses may be hampered by cultural differences among responders, as with the Humberto Vidal gas explosion in Puerto Rico in $1996,{ }^{126}$ and by an assault of untrained volunteers who arrive at a disaster scene eager but ill prepared to help, as with the 2007 oil spill from the Cosco Busan. ${ }^{127}$

Buck et al. conclude that "ICS works well when official responders have trained in ICS and have a strong sense of community." ${ }^{28}$ The study also agrees with practitioners and prior researchers that "the deficiencies identified are not inherent in ICS but rather are related to inadequate im-

123. Id.

124. Id. at 9.

125. Id. at $11,20$.

126. On November 21, 1996, at about 8:30 a.m., a leak from a propane gas pipeline resulted in a massive explosion in a commercial district in San Juan, Puerto Rico. The explosion destroyed the Humberto Vidal building and caused thirty-three deaths and several dozen more injuries. Local police and fire departments responded instantly and, within half an hour of the explosion, an ICS structure was established with the appointment of an incident commander. While the search for possible survivors within the building rubble was an immediate need, a clash of languages, backgrounds, and cultures may have risen instantly as Urban Search and Rescue teams arrived on the island that same day from such distant locales as Florida, New York, and California. See NAT'L Transp. Safety Bd., Pipeline Accident Report: SAN Juan Gas Company, Inc. / ENRON Corp. Propane Gas Explosion in SAN JuAn, Puerto Rico, ON November 21, 1996, at 9-11 (1997), available at http://www.ntsb.gov/doclib/reports/1997/PAR9701.pdf.

127. On November 7, 2007, a spill in San Francisco Bay occurred when the container ship Cosco Busan grazed a tower of the Bay Bridge, causing a gash in the side of the vessel that released some 58,000 gallons of oil into the water. In response, some 1,200 volunteers appeared on beaches to assist with cleanup efforts, prompting new, streamlined procedures for health and safety training and new state planning to ensure more effective integration and coordination of volunteer efforts in the future. See Robert Selna et al., Volunteers Rush Through Training, Start Cleanup, SFGATE.COM (Nov. 13, 2007), http://www.sfgate.com/cgi-bin/article.cgi?file=/c/a/2007/11/13/MN24TB2L0.DTL; see also California Volunteers Disaster Corps, CAL. VOLUNTEERS, http://www.californiavolun teers.org/index.php/calvol/program_DisasterCorps/ (last visited Apr. 21, 2013).

128. Buck, supra note 57 , at 21 . 
plementation." 129 The remedy for these deficiencies may thus lie outside of ICS itself. Such remedies may, in fact, be found within allied systems such as the National Incident Management System, which specifies training requirements for ICS positions. ${ }^{130}$

As all responders and reviewers appear to agree, the Incident Command System is not perfect. Yet over time, ICS has proven itself as a highly reliable system for managing disasters, emergencies, and other incidents requiring coordinated efforts within and among organizations. As the following Part will show, since 2001, ICS has endured and evolved through some of the most challenging trials in American history, including 9/11 and Hurricane Katrina.

\section{LAW AND APPLICATION OF THE INCIDENT COMMAND SYSTEM}

While the Incident Command System has been known in the response community for four decades now, it has become widely applied only within the past decade or two. Prompted by national catastrophes including 9/11, Hurricane Katrina, and the Deepwater Horizon, the use of ICS grew rapidly within the last ten years, propelled by forces including public outrage, executive order, and legislative changes. This Part will examine the evolving and expanding applications of ICS in the United States propelled by such forces.

\section{A. ICS and Response to Oil and Hazardous Substances}

One type of case where ICS has long been the rule is responses to oil spills and releases of hazardous substances into the environment. Incidents such as the Enbridge oil spill in Michigan and the Deepwater Horizon disaster in the Gulf of Mexico are subject to federal statutes including the Clean Water Act, ${ }^{131}$ Oil Pollution Act, ${ }^{132}$ and the Comprehensive Environmental Response, Compensation, and Liability Act (CERCLA), ${ }^{133}$ better known as "Superfund." Environmental responses under these three statutes are guided by one set of federal regulations known as the "National Contingency Plan" (NCP). ${ }^{134}$

129. Id.

130. See ICS Resource Center, FED. EMERGENCY MGMT. AGENCY, http://training.fema.gov/ EMIWeb/IS/ICSResource/TrainingMaterials.htm (last visited Apr. 21, 2013).

131. See generally Clean Water Act $\S 311,33$ U.S.C. $§ 1321$ (2010).

132. See generally Oil Pollution Act (OPA), 33 U.S.C. $\$ \S 2701-2762$ (2006).

133. Comprehensive Environmental Response, Compensation, and Liability Act (CERCLA), 42 U.S.C. $\S 9601$ (2010)

134. National Oil and Hazardous Substances Pollution Contingency Plan, 40 C.F.R. Part 300 (2010). In a twist on administrative law, which generally assumes that statutes come before their implementing regulations, the first National Contingency Plan actually predates the modern Clean Water Act, CERCLA, and the Oil Pollution Act. The original NCP was developed in response to a 
Prompted by the Exxon Valdez oil spill in 1989 and passage of the Oil Pollution Act in 1990, ${ }^{135}$ the EPA amended the NCP in 1994 for purposes including adoption of the Incident Command System for oil and hazardous substances responses. ${ }^{136}$ While the NCP provides only a fleeting direct reference to the "Incident Command System," pressly embraces the ICS concept of unified command. ${ }^{138}$ By emphasizing unified command, the EPA signaled that its version of ICS "is not one of the several systems currently in use by local fire fighters around the country and separately referred to as 'the' traditional incident command system." 139 Under "traditional" ICS, a single incident would be handled by a single incident commander. By contrast, under a unified command structure, a single incident may be handled by two or more incident commanders, working together as unified command to achieve a common set of objectives. ${ }^{140}$ In the ICS response to the 2010 Enbridge oil spill, for example, unified command included the EPA, the Michigan

massive oil spill from the tanker Torrey Canyon off the coast of England in 1967, leading the United States to realize the need for a comprehensive system of spill reporting and response. See National Oil and Hazardous Substances Pollution Contingency Plan Overview, Envtl. Prot. Agency, http://www.epa.gov/oem/content/lawsregs/ncpover.htm (last visited Apr. 21, 2013). Following the 1968 publication of the NCP, passage of the modern Clean Water Act in 1972, CERCLA in 1980, and OPA in 1990 embraced requirements of the NCP and required amendments to it. See Clean Water Act § 311(d)(1), 33 U.S.C. § 1321(d)(1) (2010) ("The President shall prepare and publish a National Contingency Plan for removal of oil and hazardous substances ...."); CERCLA § 105(a), 42 U.S.C. § 9605(a) ("Within one hundred and eighty days after December 11, 1980, the President shall ... revise and republish the national contingency plan for the removal of oil and hazardous substances ....").

135. The Exxon Valdez oil spill into Alaska's Prince William Sound in 1989 prompted Congress to pass the Oil Pollution Act in 1990. "OPA 90" passed by unanimous vote, following almost fifteen years of failed efforts to achieve similar legislation before the Exxon Valdez spill. See Russell V. Randle, Oil Pollution Deskbook 3 (1991).

136. National Oil and Hazardous Substances Pollution Contingency Plan, 59 Fed. Reg. 47,384 (Sept. 15, 1994) (codified at 40 C.F.R. Part 300 (2010)).

137. See 40 C.F.R. $\S 300.150$ (a) (2010) ("The National Response System [of which the NCP was a part] meets the requirements . . concerning use of an incident command system."). The ICS "requirements" cited in the NCP refer to worker health and safety regulations promulgated by the Occupational Safety and Health Administration (OSHA). See 29 C.F.R. § 1910.120(q)(3)(i)-(ix) (2010). Among other requirements, the OSHA regulations provide, "The senior emergency response official responding to an emergency shall become the individual in charge of a site-specific Incident Command System (ICS). All emergency responders and their communications shall be coordinated and controlled through the individual in charge of the ICS ...." Id. § 1910.120(q)(3)(i).

138. See, e.g., 40 C.F.R. $\S 300.105$ (d) (2010) ("The basic framework for the response management structure is a system (e.g., a unified command system) that brings together the functions of the Federal government, the state government, and the responsible party to achieve an effective and efficient response, where the [on-scene coordinator] maintains authority." (emphasis added)); see also id. at Fig. 1a (depicting a "Unified Command Structure").

139. 59 Fed. Reg. at 47,387 pmbl.

140. EPA ICS HANDBOOK, supra note 61. 
Department of Natural Resources and Environment, the City of Battle Creek, and Enbridge (as the responsible party). ${ }^{141}$

Having a party, such as Enbridge, that is legally responsible for an incident working alongside regulatory agencies within unified command obviously raises issues of law, legal ethics, and public perceptions. ${ }^{142} \mathrm{On}$ the other hand, having the responsible party on board may provide ready access to resources and experts that are beyond the ready reach of government. In any case, consistent with the National Contingency Plan, the Incident Command System remains the rule in the United States for integrated responses to oil spills and hazardous substances.

\section{B. ICS and Response to $9 / 11$}

\section{ICS on $9 / 11$}

Some thirty years after the creation of the Incident Command System, the events of September 11, 2001, tragically demonstrated how uncoordinated responses to disasters may exacerbate injuries and losses of life. In its extraordinary accounting of the events leading up to and following the terrorist attacks on that day, the 9/11 Commission acknowledged the astounding heroics and the staggering losses of life among agencies responding on 9/11. ${ }^{143}$ At the same time, the Commission also documented how failures of incident command and communications hampered the response and likely led to greater casualties and other impacts.

Two months before 9/11, Mayor Giuliani issued a directive, "Direction and Control of Emergencies in the City of New York," which promoted ICS concepts such as unified command and the designation of incident commanders. ${ }^{144}$ After a meticulous review of the record, the Commission concluded that it was "clear, however, that the response operations" at the World Trade Center, "lacked the kind of integrated communications and unified command contemplated in the directive."145

141. Envtl. Prot. Agency, Pollution / Situation Report: Kalamazoo River / ENBRIDGE SPILL-REMOVAL POLREP-SITREP (2010), available at http://www.epa.gov/ enbridgespill/pdfs/sitreps/20100819_sitrep27.pdf.

142. See infra note 389 (speculating about BP's motives in the Deepwater Horizon response).

143. 9/11 COMM'N, FinAl REPORT OF THE NATIONAL COMMISSION ON TERRORIST ATTACKS UPON THE UNITED STATES (1st ed. 2004) [hereinafter 9/11 COMMISSION REPORT]. On 9/11, the Fire Department of New York (FDNY) suffered 343 fatalities, the single largest loss of life of any emergency response agency in history. This was followed by thirty-seven fatalities among the Port Authority Police Department (PAPD), which ranks as the highest loss of any police force in history. The New York Police Department (NYPD) lost twenty-three people on that day, which ranks as the second highest loss among any police force. Id. at 311.

144. Id. at 319 .

145. Id. 
Despite the directive's call for unified command, "the FDNY and NYPD each considered itself operationally autonomous." "146 Of course, beyond the FDNY and NYPD, the response to the World Trade Center attacks was supported - and complicated - by agencies from all levels of government: federal, state, and local. ${ }^{147}$ In general, the Commission observed that "incident commanders from responding agencies lacked knowledge of what other agencies and, in some cases, their own responders were doing." quences on 9/11. For example, after the South Tower collapsed at 9:58 a.m., many chiefs and firefighters in the North Tower remained unaware and perished when the North Tower collapsed twenty-nine minutes later. ${ }^{149}$

While the extraordinary circumstances of both the World Trade Center and the Pentagon on 9/11 defy comparisons, the Commission did note some differences in the responses to each attack. The Commission observed:

While no emergency response is flawless, the response to the $9 / 11$ terrorist attack on the Pentagon was mainly a success for three reasons: first, the strong professional relationships and trust established among emergency responders; second, the adoption of the Incident Command System; and third, the pursuit of a regional approach to response. ${ }^{150}$

The Commission specifically credited the Incident Command System with helping Pentagon responders to overcome "the inherent complications of a response across jurisdictions." ${ }^{\text {151 }}$ As in New York, the at-

146. Id. at 285. For a detailed examination of the communication failures and cultural gaps between the FDNY and NYPD hampering the response on 9/11, see Jim Dwyer et al., 9/11 Exposed Deadly Flaws in Rescue Plan, N.Y. TIMES, July 7, 2002, at A1.

147. Principal first responders to the World Trade Center on 9/11 were the FDNY, NYPD, PAPD, and the Mayor's Office of Emergency Management. 9/11 COMMISSION REPORT, supra note 143, at 281. However, in addition to these agencies, other responding agencies included FEMA and the New York City Department of Health, id. at 293, along with the U.S. Environmental Protection Agency, the Occupational Safety and Health Administration, and the New York State Department of Environmental Conservation. See, e.g., Walter E. Mugdan, Environmental Law Issues Raised by Terrorist Events in 2001, 7 ALBANY L. ENVTL. OUTLOOK J. 67 (2002) (noting the observations and analysis from the Regional Counsel of EPA Region 2 in New York).

148. 9/11 COMMISSION REPORT, supra note 143, at 305.

149. Id. at 307-08. Of course, had all responders in the North Tower known of the collapse of the South Tower, it is not likely that they all would have evacuated. However, several surviving firefighters later expressed belief that they and others would have evacuated more urgently had they known of the South Tower's collapse. Id. at 307.

150. Id. at 314 (emphasis added). Concurring in this assessment, one scholarly study concluded, "The use of ICS and unified command in the Pentagon incident response was in many ways a textbook example of high effectiveness." Buck, supra note 57, at 6.

151. 9/11 COMMISSION REPORT, supra note 143, at 314. 
tack on the Pentagon prompted response across disciplines (e.g., fire, law enforcement) and at all levels of government. ${ }^{152}$ Consistent with ICS, the Pentagon response was overseen by an incident commander, provided by the Arlington County Fire Department, and an incident command post was promptly established near the crash site to allow assessment of the situation at all times. ${ }^{153}$

Despite the relative success of the Pentagon response, Arlington County's "after-action report" identified significant problems with incident command. ${ }^{154}$ These included confusion over the names for organizational units and difficulties caused by freelancing units self-dispatching to the scene. ${ }^{155}$ Acknowledging the successes and failures with the responses at both the Pentagon and World Trade Center, the 9/11 Commission concluded that "the problems in command, control, and communications that occurred at both sites will likely recur in any emergency of similar scale. The task looking forward is to enable first responders to respond in a coordinated manner with the greatest possible awareness of the situation." 156 To meet this challenge directly, the 9/11 Commission offered the following recommendation: "Emergency response agencies nationwide should adopt the Incident Command System (ICS). When multiple agencies or multiple jurisdictions are involved, they should adopt a unified command. Both are proven frameworks for emergency response."157

152. Agencies responding to the Pentagon attack included, for example, the FBI, FEMA, the Virginia State Police, the Virginia Department of Emergency Management, and the fire departments of Alexandria, Fairfax County, and the District of Columbia. Id.

153. Id. at 314-15.

154. See generally Arlington CnTy., After-Action Report on the Response to the SEPTEMBER 11 TERRORIST ATTACK ON THE PENTAGON, available at http://www.arlingtonva.us/ departments/Fire/Documents/after_report.pdf.

155. Id. at A-25-26.

156. 9/11 COMMISSION REPORT, supra note 143, at 315.

157. Id. at 397. In addition to this express endorsement of ICS for government agencies, more subtly, the 9/11 Commission also indicated support for adoption of ICS in the private sector. In a separate recommendation, the 9/11 Commission endorsed "the American National Standard Institute's recommended standard for private preparedness" as a means of promoting employee safety, business continuity, and protection of critical infrastructure. Id. at 398. This recommended standard, which encourages voluntary use of ICS, was developed by the National Fire Protection Agency (NFPA) and is known as "NFPA 1600." See NAT'L FIRE PROT. Ass'N, NFPA 1600: STANDARD ON Disaster/EMERgency Management and Business Continuity Programs, at Annex E (2007 ed.), available at $\mathrm{http} / / / \mathrm{www} . n f p a . o r g /$ assets/files/pdf/nfpa1600.pdf. For a more detailed examination of NFPA 1600 as a voluntary preparedness standard, see Nicholson, Seeking Consensus, supra note 43 , at $534-40$. 


\section{ICS After $9 / 11$}

In short order, the Commission's recommendation for adopting ICS nationwide was accepted and mandated by the federal government. In 2002, Congress passed the Homeland Security Act, signed into law on November 25, 2002. ${ }^{158}$ Most famously, the Homeland Security Act established the U.S. Department of Homeland Security (DHS), ${ }^{159}$ created through a massive reorganization and consolidation of federal workers from twenty-two agencies, ${ }^{160}$ including FEMA and the U.S. Coast Guard. Less visibly, but consistent with the 9/11 Commission's recommendation, the Homeland Security Act also set in motion a process leading to the effective mandate of the Incident Command System nationwide.

Through the Homeland Security Act, Congress charged DHS with "building a comprehensive incident management system with Federal, State, and local government personnel, agencies, and authorities, to respond to [terrorist] attacks and disasters." 161 Four months later, on February 28,2003 , the President acted in furtherance of this charge by issuing Homeland Security Presidential Directive 5 (HSPD-5). ${ }^{162}$ HSPD-5 directed the Secretary of Homeland Security to "develop . . . and administer a National Incident Management System."163 NIMS was intended to provide a "consistent nationwide approach for Federal, State, and local governments to work effectively and efficiently together to prepare for, respond to, and recover from domestic incidents, regardless of cause, size, or complexity." ${ }^{164}$ Importantly, HSPD-5 required that the National Incident Management System "include a core set of concepts . . covering the incident command system." "165

The Secretary of Homeland Security took on the charge of developing the National Incident Management System (incorporating ICS) with breathtaking speed for a burgeoning bureaucracy, issuing a final NIMS document on March 1, 2004. ${ }^{166}$ Upon the issuance of this NIMS document, HSPD-5 required all federal agencies to implement the Incident Command System for domestic incidents.

158. Homeland Security Act of 2002, Pub. L. No. 107-296, 116 Stat. 2135 (2002) (codified at 6 U.S.C. $\$ \$ 101-557(2010))$.

159. 6 U.S.C. § 111(a) (2010).

160. Press Release, White House, Fact Sheet: President Highlights a More Secure America on First Anniversary of Department of Homeland Security, Office of the Press Secretary (Mar. 2, 2004), available at http://www.whitehouse.gov/news/releases/2004/03/20040302-4.html.

161. 6 U.S.C. § 314(a)(5) (2010) (emphasis added).

162. Press Release, The White House, Homeland Sec. Presidential Directive/HSPD-5 (Feb. 28, 2003) [hereinafter HSPD-5], available at http://www.fas.org/irp/offdocs/nspd/hspd-5.html.

163. Id. $₫ 15$.

164. Id.; see also NIMS DocuMENT, supra note 22.

165. HSPD-5, supra note 162, 915 (emphasis added).

166. See Nicholson, Seeking Consensus, supra note 43, at 492-94 \& nn.10-30. 
On its face, HSPD-5, as a federal directive, only applies to federal departments and agencies. However, HSPD-5 also invokes the mighty power of the federal purse to effectively compel adoption of NIMS and ICS by all levels of government. In brief but powerful terms, HSPD-5 specifically provided, "Beginning in Fiscal Year 2005, Federal departments and agencies shall make adoption of the [National Incident Management System] a requirement . . . for providing Federal preparedness assistance through grants, contracts, or other activities." ${ }^{167}$ In September 2004, while rolling out this new condition for federal funding, DHS declared that "ICS is a critical component of the NIMS" and called for nationwide adoption of the Incident Command System in unequivocal terms:

If State, territorial, tribal, and local entities are not already using ICS, you must institutionalize the use of ICS (consistent with the concepts and principles taught by DHS) across the entire response system . . . . All Federal, State, territory, tribal, and local jurisdictions will be required to adopt ICS in order to be compliant with NIMS. ${ }^{168}$

By the time DHS issued this unequivocal mandate, the ICS concept was already thirty years old. NIMS, however, was new, with a broader objective to help prevent and mitigate the impacts of all incidents, providing a systematic approach to training and exercises, personnel qualifications, equipment certification, information management, mutual aid agreements, research and development, and other preparedness measures. ${ }^{169}$ In view of the sweeping scope of NIMS, local governments and other stakeholders complained about the federal mandate to begin complying with NIMS in the very year that NIMS was published. ${ }^{170}$

Despite the federal mandate and the growing adoption of the Incident Command System across the country, the changes in incident management inspired by $9 / 11$ required time to take root. Unfortunately, in the very year that the National Incident Management System was being

167. HSPD-5, supra note 162 , 920

168. Letter from Tom Ridge, Sec'y, Dep't of Homeland Sec., to State Governors (Sept. 8, 2004), reprinted in Nicholson, Seeking Consensus, supra note 43, at 555-59. To clarify the criteria for NIMS compliance, HSPD-5 also directed the DHS Secretary to "develop standards and guidelines for determining whether a State or local entity has adopted the NIMS." HSPD-5, supra note 162 , 9 20. These standards may be identified today through the NIMS Resource Center, managed by FEMA and available on-line at www.fema.gov/emergency/nims/.

169. See generally NIMS DocUMENT, supra note 22, at 7-8.

170. By one estimate, upon its initial publication, NIMS had "518 measurable requirements," making compliance by the start of fiscal year 2006 "a Herculean and perhaps unreasonable task." Nicholson, Seeking Consensus, supra note 43, at 547 (quoting Los Angeles County Fire Chief Michael Freeman). 
rolled out to the country, the Gulf Coast states were struck by the single most destructive disaster in American history. ${ }^{171}$

\section{ICS and Hurricane Katrina}

Whatever else might be said about Hurricane Katrina, it cannot be said that we failed to see it coming. Unlike the sudden and shocking attacks on 9/11, Katrina developed predictably under the watchful eyes of weather forecasters, forming as a tropical depression on August 23, 2005. ${ }^{172}$ On Friday, August 26, the National Hurricane Center issued a warning that Hurricane Katrina appeared to be headed for New Orleans. ${ }^{173}$ On Saturday, the massive evacuation of New Orleans began, with more than a million residents leaving the area in just over twenty-four hours. ${ }^{174}$ When Katrina made landfall in the early morning of Monday, August 29, 2005, television crews were in place to capture it as a live, televised event. ${ }^{175}$

New Orleans may have been the hardest hit, but the storm's surge reached all the way across the Gulf Coast from Texas to central Florida. ${ }^{176}$ In terms of land mass, "Katrina laid waste to some 90,000 square miles, an area the size of the United Kingdom." $" 177$ In terms of lives, at least 1,836 people died as a result of the hurricane and the ensuing floods. In terms of economic losses, Katrina far exceeded the damage from the 9/11 terror attacks or any other single disaster to strike the United States. ${ }^{178}$ Indeed, Hurricane Katrina in many ways defied convention-

171. While Hurricane Katrina will always overshadow the narrative and memories of 2005 for most people, the 2005 Atlantic hurricane season also produced a record fifteen hurricanes, including the most Category Five hurricanes in a single season: Katrina, Rita, and Wilma. ROBERT R.M. Verchick, Facing CATAstrophe: EnVIRONMENTAL ACtion FOR a POST-Katrina World 225 (2010).

172. A NATION STILl UNPREPARED, supra note 1 , at 22.

173. Id. In addition to warnings through regular channels, Max Mayfield, Director of the National Hurricane Center, also took the extraordinary step of personally calling the governors of the affected states on the weekend before hurricane landfall. $I d$. at 5 .

174. Id. at 24 .

175. For an extraordinarily detailed daily accounting of Hurricane Katrina from tropical depression to landfall, see THE White House, THE FedERAL RESPONSE to HuRRICANE KATRINA: LESSONS LEARNED (2006) [hereinafter LESSONS LEARNED]. For a humanizing and harrowing view of these same events, from the perspective of one family who evacuated from New Orleans and their father who stayed behind, see DAVE EGGERS, ZEITOUN (2009).

176. VERCHICK, supra note 171 , at 2.

177. A NATION STILL UNPREPARED, supra note 1, at 21.

178. In 2005 dollars, Hurricane Katrina was estimated to have caused economic damages of $\$ 125-150$ billion. The 9/11 terror attacks were estimated to have caused $\$ 87$ billion in damages, and Hurricane Andrew (the next most destructive hurricane) was estimated to have caused $\$ 48.5$ billion in damages. A NATION STILL UNPREPARED, supra note 1, at 37. 
al metrics and genre; for lawyers and legal scholars, it even helped usher in the new field of disaster law. ${ }^{179}$

Given the sheer scale of Hurricane Katrina, it is doubtful that even the best plans and policies, flawlessly implemented, could have spared the region from devastating impacts. The collective response to Katrina, however, was far from flawless. The infamously anemic response to Katrina was even more incomprehensible in that it was anticipated not just by weather forecasters six days before landfall, but by a whole suite of policymakers, engineers, emergency professionals, and others months and even years in advance. ${ }^{180}$ In 2004 , the year before Katrina hit, federal, state, and local officials had even participated in a planning exercise, dubbed "Hurricane Pam," that specifically anticipated massive flooding in New Orleans. ${ }^{181}$ In April 2005, the Department of Homeland Security sponsored a large-scale exercise, "Top Officials 3" (TOPOFF 3), involving responders from all levels of government in a scenario implementing the newly minted National Incident Management System. According to a report by the Homeland Security Inspector General, the TOPOFF exercise revealed "a fundamental lack of understanding for the principles and protocols set forth in . . NIMS." " 182 This lack of understanding for the National Incident Management System reflected resoundingly in the response to Hurricane Katrina four months later.

Through all the official post-mortems that followed Katrina, including voluminous reports from the U.S. Senate, ${ }^{183}$ the House of Representatives, ${ }^{184}$ and the White House, ${ }^{185}$ the lack of planning, coordination, and leadership was noted at every level of government. Part of the problem could be explained by the massive shifts in governmental organization and orientation that had been wrought by $9 / 11$. These shifts included

179. See FARBER ET AL., supra note 16, at xxi (noting that in the years since Katrina (2005) and the first edition of the DisASTER LAW (2006), "courses on disaster issues have begun to spring up around the country, and a small, but growing, body of legal scholarship has emerged").

180. As the Senate committee noted, the potentially devastating threat of a catastrophic hurricane to the Gulf Coast and New Orleans in particular has been known for decades. In 1965, Hurricane Betsy caused flooding in New Orleans that in some ways was remarkably similar to flooding from Katrina. In 1969, Hurricane Camille brought devastation to the Gulf Coast. Hurricane Georges hit the Gulf Coast in 1998, and prompted the State of Louisiana to ask FEMA pointedly for assistance with hurricane planning. A NATION STILL UNPREPARED, supra note 1, at 4.

181. Id. After "Hurricane Pam" in 2004, lessons learned were still being translated in draft plans in 2005 when the real Hurricane Katrina struck later that year. Id.

182. Id. at 552.

183. See id. (spanning 732 pages).

184. SeleCt Bipartisan COMmitTEe to INVESTIGATE THE PREPARATION FOR AND RESPONSE to HurRicANe Katrina, A FAilure of Initiative: Final RePORT, H.R. REP. No. 109-377 (2006) [hereinafter A FAILURE OF INITIATIVE].

185. LESSONS LEARNED, supra note 175, at ch. 3, n.130. 
the placement of FEMA under the Department of Homeland Security; ${ }^{186}$ the DHS creation of a new coordinating figure, the "principal federal official," notwithstanding the federal coordinating officer established by the Stafford Act; ${ }^{187}$ and an overall national emphasis on terrorist threats. ${ }^{188}$

As with the Homeland Security Act in the year following 9/11, Congress stepped in the year after Hurricane Katrina with new legislation: the Post-Katrina Emergency Management Reform Act (PostKatrina Act). ${ }^{189}$ The new law attempted to fix a number of the problems identified with the Katrina response - even if it meant undoing some of the "reforms" in response to 9/11. The Post-Katrina Act, for example, gave FEMA a measure of autonomy within DHS, ${ }^{190}$ designated the FEMA Administrator as a direct advisor to the President, ${ }^{191}$ and affirmed FEMA's primary mission to "reduce the loss of life and property and protect the Nation from all hazards."192

One thing the Post-Katrina Act did not do, however, was alter the fundamental, nationwide mandate to adopt the National Incident Management System, including the Incident Command System. Quite the contrary, the post-mortems recognized that major deficiencies in the Katrina response often simply reflected failures to implement the Incident Command System properly. In particular, critical reviews later

186. A NATION STILl UNPREPARED, supra note 1, at 552.

187. Id.; see Stafford Act $§$ 302(a), 42 U.S.C. § 5143(a) (2010) ("Immediately upon his declaration of a major disaster or emergency, the President shall appoint a Federal coordinating officer to operate in the affected area."). Where he deems necessary, the President shall also request the Governor of an affected State to appoint a State coordinating officer for purposes of coordinating state and local disaster assistance efforts with those of the Federal government. Id. $\S 5143$ (c).

188. Commenters on draft versions of NIMS had specifically voiced concerns that the new government policies focused too heavily on terrorism, to the possible loss of attention for natural disasters and other hazards. Nicholson, Seeking Consensus, supra note 43, at 491-97. Consistent with that focus, the TOPOFF 3 exercise, four months before Katrina, involved over 10,000 participants from federal, state, tribal, and local agencies, as well as the private sector, all engaged in a training scenario involving terrorist strikes. See The TOPOFF 3 Full-Scale Exercise, DEP'T OF HOMELAND SEC., http://www.dhs.gov/files/training/editorial_0594.shtm (last visited May 30, 2012).

189. Post-Katrina Emergency Management Reform Act of 2006, Pub. L. No. 109-295, 120 Stat. 1355 (2006) [hereinafter Post-Katrina Act] (codified in scattered sections of 6 U.S.C.).

190. Among other things, the Post-Katrina Act recognized FEMA as a "distinct entity" with DHS; exempted FEMA from DHS reorganizational authority; and limited DHS's authority to reduce FEMA's responsibilities or divert its resources. See 6 U.S.C. $\S 316$ (a)-(c) (2010).

191. Id. $\S 313(\mathrm{c})(4)$. For a reflection of the widely panned performance of FEMA head Michael Brown (also known as "Heckuva Job Brownie") during Hurricane Katrina, see, for example, A NATION STILl UNPREPARED, supra note 1, at 556. The Post-Katrina Act also included extraordinary provisions to establish some minimal level of qualifications for appointment as FEMA Administrator. See 6 U.S.C. $\S 313(\mathrm{c})(2)$ (stating the FEMA Administrator must have "demonstrated ability in and knowledge of emergency management" and "not less than 5 years of executive leadership and management experience").

192. 6 U.S.C. $\S 313(b)(1)$ (emphasis added). 
found that the Katrina response failed to meet the ICS principles of unity of command and unified command. Behind these two concepts is an intention and expectation that proper use of ICS "clarifies reporting relationships and eliminates confusion caused by multiple, and potentially conflicting, directions and actions."

Unity of command, the ICS principle that each individual reports to one and only one supervisor, ${ }^{194}$ proved challenging and elusive as 9/11 reforms and reorganizations created an abundance of officials with unclear lines of reporting. These included the Secretary of Homeland Security, the head of FEMA, the DHS principal federal official (PFO), and the Stafford Act's federal coordinating officer (FCO). In the early days of the Katrina response, Michael Brown served as both the head of FEMA and the designated PFO - a "dual-hatted" role that the Senate committee later found in express violation of federal policy. ${ }^{195}$ When Brown was shortly relieved of duty after Katrina, the second principal federal official, Coast Guard Admiral Thad Allen, "went operational,"196 again in conflict with official doctrine as well as the Stafford Act, which recognizes only the federal coordinating officer as the federal official in charge of field operations. This confusion of authority between the PFO and the FCO, a violation of the principle of unity of command, was resolved only when Allen was subsequently appointed as both federal coordinating officer and the principal federal official. ${ }^{197}$ Addressing this confusion directly, Congress through the Post-Katrina Act later provided that the "Principal Federal Official ... shall not - (A) direct or replace the incident command structure established at the incident; or (B) have directive authority over the . . . Federal Coordinating Officer, or other Federal and State officials." 198 Accordingly, the new law affirmed and strengthened support for both the Incident Command System and the federal coordinating officer acting within it.

Beyond the confusion of authority at the federal level during the Katrina response, there was widespread confusion of authority at all levels of government. At the local level, this confusion of authority, contrary to the principle of unity of command, may have resulted in truly tragic

193. LESSONS LEARNED, supra note 175, at 13.

194. See supra note 73 and accompanying text.

195. A Nation Still UnPrepared, supra note 1, at 556. See DeP'T of Homeland Sec., NATIONAL RESPONSE FRAMEWORK 66 (2008) [hereinafter NATIONAL RESPONSE FRAMEWORK] ("Once formally designated for an ongoing incident, a PFO relinquishes the conduct of all previous duties to focus exclusively on his or her incident management responsibilities.").

196. A FAILURE OF INITIATIVE, supra note 184 , at 189.

197. More than just a confusion of position titles and reporting obligations, liabilities could arise from an individual exceeding his legal authority to obligate funds. See id. at 190 ("Only the FCO has authority to obligate money.").

198. 6 U.S.C. $§ 319(c)(2)(2010)$. 
consequences. At the Superdome, for example, where more than 20,000 evacuees had gathered and both the National Guard and the New Orleans Police Department had established a presence, there was no consensus on who was in charge, with both agencies denying lead responsibility. ${ }^{199}$ Similarly, at the Cloverleaf, an elevated highway structure where up to 7,000 people had gathered, senior officials for both the National Guard and state police did not know who was supposed to be in charge. ${ }^{200}$ Outside of these central locations, in areas where the Red Cross attempted to establish emergency shelters, the Red Cross was denied access by local law enforcement. ${ }^{201}$ Agency squabbles and confusion over command literally deprived people of shelter and left lives hanging in the balance.

Beyond the failures of unity of command, Katrina revealed widespread failures with establishing a unified command. ${ }^{202}$ In Louisiana, unified command was attempted, at least initially, to include the FCO from FEMA, a state coordinating officer (SCO) from the Louisiana Office of Homeland Security and Emergency Preparedness, and a defense coordinating officer (DCO) from the U.S. Department of Defense. ${ }^{203}$ As unified command, these three officials should have established and maintained control of field operations in Louisiana, but they did not. Instead, command was hindered, as on $9 / 11$, by freelancing agencies "just showing up" or agencies bypassing the command structure. ${ }^{204}$ For example, the head of Louisiana's National Guard bypassed unified command and requested troops directly through the National Guard Bureau and the Department of Defense. ${ }^{205}$

Part of the failure of unified command in Louisiana could be attributed to the direct hit the state took from Hurricane Katrina and the breach of the levees that followed. Part of the failure could be attributed to our American system of federalism, ${ }^{206}$ with the federal government infamously waiting for state and local officials - overwhelmed and often victims of the hurricane themselves ${ }^{207}$ - to issue proper requests for fed-

199. See A FAILURE OF INITIATIVE, supra note 184, at 185.

200. Id. at 186 .

201. Id. at 349 .

202. See supra notes 75-76 and accompanying text (unified command).

203. A NATION STILL UNPREPARED, supra note 1, at 561.

204. A FAILURE OF INITIATIVE, supra note 184, at 189.

205. Id. at 561-62.

206. See Erin Ryan, Federalism and the Tug of War Within: Seeking Checks and Balance in the Interjurisdictional Gray Area, 66 MD. L. REV. 503, 532 (2007) ("While the President's senior advisers fiddled with federalism, New Orleans drowned.").

207. Among other local impacts, the City of New Orleans had to abandon its emergency operations center when City Hall flooded, cutting off power from emergency generators. Numerous other local operations centers, including the headquarters for the Louisiana National Guard, also had to be abandoned due to flooding. A FAILURE OF INITIATIVE, supra note 184, at 185. 
eral support. ${ }^{208}$ Part of the failure could be explained by a lack of personnel needed to support the ICS structure, both in terms of numbers and in terms of key individuals. ${ }^{209}$ But according to the Senate report, "[p]erhaps the most significant reason for the failure to establish unified command in Louisiana is the lack of NIMS . . training." ${ }^{210}$ Indeed, as the Senate report noted, "the state brought in consultants a few days after Katrina made landfall to give basic ICS courses to [civilian response personnel] and to members of the Louisiana National Guard." 211

In contrast with Louisiana, the State of Mississippi appeared to demonstrate considerably more success with its response to Hurricane Katrina. This success was attributed, in part, to "extensive prior training on the Incident Command System received by state and local responders in Mississippi." ${ }^{212}$ Of course, successful responses to Katrina were also demonstrated by other state and federal agencies, most notably the U.S. Coast Guard, for whom training represents a fundamental qualification for duty. ${ }^{213}$

After Katrina, in its "Lessons Learned" report, the White House reemphasized the critical need for training, specifically recommending that the Department of Homeland Security "institute a formal training program on the NIMS . . . for all department and agency personnel with incident management responsibilities." 214 In issuing this recommendation, the White House cogently observed, "The key to the implementation of ICS is training." 15 Through the Post-Katrina Act of 2006, Congress adopted the recommendation of the White House and the House and Senate reports by establishing the National Integration Center within FEMA. ${ }^{216}$ As established by Congress, the National Integration Center

208. As the House Select Bipartisan Committee observed, "[F]aith in federalism alone cannot sanctify a dysfunctional system in which DHS and FEMA simply wait for requests for aid that state and local officials may be unable or unwilling to convey." Id. at $\mathrm{x}$.

209. A NATION STILL UNPREPARED, supra note 1 , at 563.

210. Id. at 562 .

211. Id.

212. Id. at 564. In fact, the state coordinating officer for Mississippi was critical of the weak knowledge of NIMS and ICS exhibited by federal responders, reporting, "I don't think most people understood it at all. I don't think anybody read the National Response Plan ...." Id. at 563.

213. As the public witnessed, and the Senate report confirmed, "The Coast Guard performed heroically during Katrina, rescuing more than half of the 60,000 survivors who were stranded by the storm." Id. at 27. Less famously, another distinguished Katrina response agency was the Louisiana Department of Wildlife and Fisheries, the state's lead agency for search and rescue, which rescued many of the other survivors who were not rescued by the Coast Guard. Id.

214. LESSONS LEARNED, supra note 175 , at 89.

215. Id. Hammering home the point, the White House report expressly declared, "All departments and agencies should undertake an aggressive ICS training program for all personnel who may deploy during a disaster. It is essential that personnel have a working knowledge of ICS before a disaster occurs." Id.

216. See 6 U.S.C. § 319(a) (2010). 
"shall ensure ongoing management and maintenance of the National Incident Management System . . . and any successor to such system or plan.",217

Given all the lessons learned from Hurricane Katrina and the emphatic conclusions from the White House and both houses of Congress, it should be no surprise that training in NIMS and the Incident Command System accelerated in the years following Katrina. But would there be enough people trained well enough - and soon enough - to use the Incident Command System properly during the next big disaster? Five years after Katrina, the United States would face the next major trial of ICS.

\section{ICS and the Deepwater Horizon}

Officially, no one saw this coming. When British Petroleum (BP) submitted their exploration plan for the Macondo well in the Gulf of Mexico in February 2009, they asserted that it is "unlikely that an accidental oil spill release would occur from the proposed activities." 218 In April 2009, the former Minerals Management Service of the U.S. Department of the Interior approved BP's plan with a "categorical exclusion" under the National Environmental Policy Act. ${ }^{219}$ With hindsight, one commentator remarked, "What we had here was willful blindness." 220

Twelve months after BP's plan was approved, the "unlikely" spill came to pass as the Macondo well was being completed deep in the waters of the Gulf of Mexico. On April 20, 2010, an explosion tore through the Deepwater Horizon drill rig, killing eleven crewmembers, injuring many others, and eventually resulting in what President Obama described as "the worst environmental disaster America has ever faced." 221

On April 22, 2010, two days after the explosion and fire on the Deepwater Horizon, the drill rig sank into the waters of the Gulf. The

217. Id. § 319(b)(1).

218. BP EXPlORATION \& PROD., InC., Initial EXPloration Plan, Mississippi CANyON BLOCK 252, $\S 14.2 .1 .5 \quad$ (2009), available at http://media.washingtonpost.com/wpsrv/nation/documents/initial_exploration_plan050410.pdf.

219. See Juliet Eliperin, U.S. Exempted BP's Gulf of Mexico Drilling from Environmental Impact Study, WASH. POST (May 5, 2010), http://www.washingtonpost.com/wpdyn/content/article/2010/05/04/AR2010050404118.html. For a lively roundtable discussion on the role of the National Environmental Policy Act and categorical exclusions in the context of the Deepwater Horizon and oil drilling in the Gulf of Mexico, see Modernizing the NEPA Process in the Context of the Gulf Disaster, ENVTL. L. INST. (Nov. 2010), http://www.eli.org/pdf/NA_4011/40.11147.pdf.

220. Houck, supra note 38, at 11037.

221. President Barack Obama, Remarks at the Oval Office to the Nation on the BP Oil Spill (June 15, 2010), available at www.whitehouse.gov/the-press-office/remarks-president-nation-bp-oilspill. 
next day, April 23, remotely operated vehicles one mile below the surface were investigating the blow-out preventer on the Macondo well when they discovered oil leaking from the end of a riser pipe where it had broken off when the Deepwater Horizon sank. ${ }^{222}$ For at least eightyseven days, through Top Kill, Junk Shot, and other failed control efforts, oil flowed from the pipe into the Gulf of Mexico. ${ }^{223}$ How much oil flowed into the Gulf during this event remains uncertain. One official government estimate put it at approximately 205 million gallons, ${ }^{224}$ a volume that would make the Deepwater Horizon spill almost twenty times larger than that of the Exxon Valdez in 1989. ${ }^{225}$ The Deepwater Horizon was not only the largest oil spill in U.S. history, but also the largest accidental spill the world has ever seen. ${ }^{226}$

The Deepwater Horizon disaster also triggered a response unlike any the world had ever seen. At its peak, the response involved more than 120 aircraft, 7,000 vessels, and 47,000 people. ${ }^{227}$ As lead agency, the U.S. Coast Guard deployed active-duty members and called up reservists from across the country. Responders joined in from other federal agencies, including the EPA, the U.S. Fish and Wildlife Service, and the National Oceanic and Atmospheric Administration. ${ }^{228}$ Some 1,100 National Guard troops from Louisiana supported the response effort, joined by scores of other federal, state, and local agencies. ${ }^{229}$ Thousands of vol-

222. NAT'L COMm. ON THE BP DEEPWATER Horizon Oil SPILl \& OfFSHORE DRILLing, DeEP Water: The Gulf Oil Disaster and the Future of Offshore Drilling, Report to the PRESIDENT (2011) [hereinafter DEEPWATER COMMISSION].

223. Id. at 148-65. The flow of oil was first contained through a test of "static kill" on July 15. After that successful test, mud and then cement were pumped into the well and the static kill was declared a success on August 4, 2010. Id. at 167.

224. Id. at 167-68 (4.9 million barrels x 42 gallons per barrel); see Clean Water Act $\S$ 311(a)(13), 33 U.S.C. § 1321(a)(13) (defining "barrel").

225. Zygmunt J.B. Plater, Learning from Disasters: Twenty-One Years After the Exxon Valdez Oil Spill, Will Reactions to the Deepwater Horizon Blowout Finally Address the Systemic Flaws Revealed in Alaska? 40 ENVTL. L. REP. 11041, 11041 (Nov. 2010). The Exxon Valdez spill is commonly estimated to have released approximately 11 million gallons of crude oil into the waters of Alaska's Prince William Sound. Id.

226. See Rebecca M. Bratspies, A Regulatory Wake-Up Call: Lessons from BP's Deepwater Horizon Disaster, 5 Golden Gate U. ENVTL. L.J. 7, 19 n.80 (2011) (noting that the only oil spill surpassing that of the Deepwater Horizon was the intentional release of oil from the Kuwaiti oil fields by the Iraqis during the First Gulf War).

227. Ray Mabus, America's Gulf Coast: A long Term Recovery Plan After the DEEPWATER HORIZON OIL SPILL 2 (2010), available at http://www.restorethegulf.gov/ sites/default/files/documents/pdf/gulf-recovery-sep-2010.pdf. By one estimate, the Deepwater Horizon response "coordinated more vessels, aircraft, and personnel than all the oil spill events in the last 20 years combined." R. Charles Epperson, A Perspective from Within Deepwater Horizon's Unified Command Post Houma 9 (Jan. 2011) (unpublished working paper Deepwater Horizon Study Group) (emphasis added).

228. DEEPWATER COMMISSION, supra note 222, at 133.

229. Id. 
unteers offered to help with wildlife rescue. ${ }^{230}$ Together with BP as the "responsible party," the "co-combatants" placed nearly 4 million feet of floating boom to capture the oil slicks, ${ }^{231}$ applied some 1.9 million gallons of chemical dispersants to break up the oil, ${ }^{232}$ and relocated 25,000 sea turtle eggs from the Gulf Coast to the Atlantic Coast of Florida. ${ }^{233}$ Meanwhile, with the riser pipe still spewing millions of gallons of oil per day one mile below the surface, the President channeled the Manhattan Project by assembling the brightest scientists of a generation to find a technical solution. ${ }^{234}$

With an army of responders including rocket scientists and shrimp fishermen, National Guardsmen and Audubon volunteers, uniformed troops and corporate executives, and with every federal, state, and local agency in the Gulf Coast seeming to play some role, the need for command and control on the Deepwater Horizon response could not have been greater. At least for a while, many seemed to wonder who was in charge and by what authority. ${ }^{235}$ For a region still recovering from Hurricane Katrina, state governments seemed to think reflexively of FEMA and the Stafford Act in the face of an environmental disaster. ${ }^{236}$ They apparently did not immediately realize that FEMA's money was not needed where the Oil Pollution Act made the responsible party liable for the full costs of the response, ${ }^{237}$ and the National Contingency Plan put the U.S. Coast Guard squarely in charge of responding to an oil spill in

230. According to the Audubon Society, more than 12,000 volunteers signed up to help during a single week in early May. Id. at 141.

231. MABUS, supra note 227 , at 2.

232. For a close examination of the science, law, and controversy surrounding the record use of dispersants on the Deepwater Horizon spill, see Abby J. Queale, Responding to the Response: Reforming the Legal Framework for Dispersant Use in Oil Spill Response Efforts in the Wake of Deepwater Horizon, 18 HASTINGS W.-Nw. J. ENVTL. L. \& POL'Y 63, 82 (2012).

233. MABUS, supra note 227, at 31.

234. The scientists were led by Dr. Steven Chu, the Secretary of Energy and Nobel Prizewinning physicist who had previously directed the Lawrence Livermore National Laboratory. Secretary Chu's team also included Tom Hunter, the Director of Sandia National Laboratories, and Richard Garwin, who helped design the world's first hydrogen bomb and had worked on extinguishing the oil fires in Kuwait after the First Gulf War. DEEPWATER COMMISSION, supra note 222, at 14849 .

235. See Griggs, supra note 20, at 59.

236. DEEPWATER COMMISSION, supra note 222, at 138 (noting that Louisiana Governor Bobby Jindal's advisors reportedly spent days trying to determine whether the Stafford Act or the National Contingency Plan applied).

237. Oil Pollution Act $§ 1002,33$ U.S.C. $§ 2702$ (2010). In general, "each responsible party for a vessel or a facility from which oil is discharged ... into or upon the navigable waters or adjoining shorelines or the exclusive economic zone is liable for the removal costs and damages ... that result from such an incident." Id. $\S 1002$ (a). The removal costs for which a responsible party is liable include "all removal costs incurred by the United States, a State, or an Indian tribe" under authorities including OPA and state law. Id. §1002(b). 
the marine environment. ${ }^{238}$ While the legal framework may have been unfamiliar to some, by 2010 , all levels of government should have been quite familiar with the operational framework for managing the response: the Incident Command System.

The Incident Command System structure begins with appointment of an incident commander. For a spill involving oil or hazardous substances, the incident commander will likely be an on-scene coordinator (OSC), a position with authority under the National Contingency Plan to direct a response and obligate funds of the government. ${ }^{239}$ For the Deepwater Horizon, the first OSC was a Coast Guard captain, who assumed command on the evening of the explosion and fire to initiate search and rescue operations. The next day, command was transferred to Rear Admiral Mary Landry, commander of Coast Guard District 8 (Gulf Coast), who served as federal on-scene coordinator (FOSC). ${ }^{240}$ On April 22 , the day the rig sank, a unified command structure was established including Admiral Landry plus senior executives from the former Minerals Management Service and BP. ${ }^{241}$ As the scope of the response broadened, unified command expanded to include state OSCs from Louisiana, Mississippi, Alabama, and Florida. ${ }^{242}$ Additional incident command posts were set up in Mobile, Alabama; St. Petersburg, Florida; and Houston, Texas. ${ }^{243}$ To provide an overall management structure, a Unified Area Command was stood up in Robert, Louisiana, and later moved to New Orleans. ${ }^{244}$ To clarify the overall command, on April 29, the Coast Guard declared the Deepwater Horizon a "Spill of National Significance,",245 permitting the appointment of a National Incident Commander. ${ }^{246}$ On

238. See 40 C.F.R. $\S 300.120(a)(1)(2010)$.

239. See National Contingency Plan, 40 C.F.R. $§ 300.322$ (b) (explaining duties of OSC). In this way, the OSC for an oil or hazardous substances spill functions similarly to a federal coordinating officer (FCO) appointed during a Stafford Act event. See sources cited supra note 187 and accompanying text (explaining the authority of FCO).

240. DEEPWATER COMMISSION, supra note 222, at 130.

241. Epperson, supra note 227, at 2.

242. Id. at 2; see also DEEPWATER COMMISSION, supra note 222, at 138.

243. Epperson, supra note 227, at 3.

244. Id. at 7.

245. See National Contingency Plan, 40 C.F.R. § 300.323.

246. This was the first declaration of a Spill of National Significance (SONS) since this authority was added to the NCP in 1994. DEEPWATER COMMISSION, supra note 222, at 136; see also National Contingency Plan, 59 Fed. Reg. 47,484 (Sept. 15, 1994) (codified at 40 C.F.R. pt. 300). The NCP provisions provide little guidance on the meaning of a SONS declaration, other than it allows the appointment of a National Incident Commander and that, for a SONS in the coastal zone, the National Incident Commander "will assume the role of the OSC in communicating with affected parties and the public, and coordinating federal, state, local, and international resources at the national level." 40 C.F.R. $\S 300.323$ (c). As the SONS provision of the NCP was originally proposed (and finally promulgated), at least one commenter expressed concern that designation of a National Incident Commander would threaten the integrity of the Incident Command System structure. In 
May 1, Homeland Security Secretary Napolitano appointed the outgoing Coast Guard Commandant, Admiral Thad Allen, as National Incident Commander. ${ }^{247}$

Admiral Allen knew command, the Incident Command System, and the National Contingency Plan. He was the highest ranking officer in the U.S. Coast Guard, ${ }^{248}$ with distinguished leadership on the Gulf Coast in response to Hurricane Katrina. ${ }^{249} \mathrm{He}$ had even overseen a simulated Spill of National Significance off the coast of Louisiana in 2002. ${ }^{250}$ Other career responders throughout the federal, state, and local governments knew the NCP and ICS too. If ICS and the National Incident Management System were still new to some responders before Katrina hit in August 2005, they were not new when the Deepwater Horizon exploded and sank in April 2010. This is particularly true when considering the intervening experiences of Hurricane Rita in September 2005, other major hurricanes including Gustav and Ike in 2008, and other national disasters as well as training exercises. ${ }^{251}$

Consistent with their training and experience in ICS, state on-scene coordinators for Louisiana, Alabama, and Mississippi participated in the Deepwater Horizon Unified Command, at least at first. However, the governors of these states, as well as other state and local officials, appeared much less familiar with ICS and resented federal control over the response. Accordingly, the governors of Louisiana, Mississippi, Alabama, and Florida declared state emergencies in response to the oil spill and began coordinating state response efforts outside of the unified command framework. ${ }^{252}$ Instead of unified command, state and local officials began creating their own response structures and plans, repudiating the area-specific oil spill response plans that they had previously developed and approved in conjunction with the federal government. Admiral Allen later called this "the social and political nullification" of the

response, EPA dismissed this concern, noting that having a senior official responsible for communications and coordination on a national level during major events simply "reflects historical practices." 59 Fed. Reg. 47,403, pmbl. (Sept. 15, 1994).

247. DEEPWATER COMMISSION, supra note 222, at 136.

248. See id. (Allen then the only four-star Admiral).

249. See sources cited supra notes 196-97 and accompanying text.

250. See DEEPWATER COMMISSION, supra note 222, at 137.

251. Perhaps the largest training exercise between Katrina and the Deepwater Horizon was TOPOFF 4 in 2007, which simulated terrorist attacks in Oregon, Arizona, and the U.S. Territory of Guam with detonation of Radiological Dispersion Devices, also known as "dirty bombs." The exercise involved more than 15,000 participants representing federal, state, territorial, and local agencies. The TOPOFF 4 Full-Scale Exercise, DEP'T OF HOMELAND SEC., http://www.dhs.gov/files/train ing/gc_1179430526487.shtm (last visited June 3, 2012).

252. DEEPWATER COMMISSION, supra note 222, at 138-39. 
National Contingency Plan, ${ }^{253}$ with its ICS principles of unified command and unity of command.

Of course, even if the National Contingency Plan was nullified socially and politically, it remained legally in effect as a rule promulgated under statutory authority. ${ }^{254}$ Admiral Allen certainly understood this, along with all other participants in the Deepwater Horizon unified command, including BP. ${ }^{255}$ However, BP's participation within unified command, consistent with ICS and the National Contingency Plan, understandably raised many questions in the eyes of the public and political leaders. $^{256}$

Aside from the broader questions suggested above, the actual implementation of ICS in the Deepwater Horizon response exhibited familiar challenges seen with prior disasters. These included (1) a lack of appropriately trained ICS personnel and (2) difficulties with assigning trained personnel to appropriate ICS positions. ${ }^{257}$ Nevertheless, for all the challenges with training and chafing over federal control, after the Macondo well was finally capped and the post-mortems began, the common view seemed to be that the ICS framework for the Deepwater Horizon response worked fairly as intended. ${ }^{258}$ For the Enbridge spill near Marshall, Michigan, happening in the same summer of 2010, re-

253. Id. at 139 .

254. See sources cited supra note 134; see also Clean Water Act § 311(c)(3)(A), 33 U.S.C. $\S 1321(\mathrm{c})(3)(\mathrm{A})(2010)$ ("Each Federal agency, State, owner or operator, or other person participating in efforts under [Clean Water Act Section 311] shall act in accordance with the National Contingency Plan. ...."). As a rule promulgated by an agency pursuant to an express grant of statutory authority, the National Contingency Plan may be considered a particular species of regulation known as a "legislative rule," carrying a binding force of law. See KenNeth Culp Davis, 2 ADMINISTRATIVE LAW TREATISE $\S \S 7: 9-7: 14$ (2d ed. 1978).

255. As BP explicitly acknowledged in its "lessons learned" report, "The entire spill response has been and will continue to be conducted under the Unified Command structure, in which ultimate authority resides in the United States Coast Guard." British Petroleum, DeEPWATER Horizon CONTAINMENT AND RESPONSE: HARNESSING CAPABILITIES AND LESSONS LEARNED (2010), available

http://www.bp.com/liveassets/bp_internet/globalbp/globalbp_uk_english/incident_response/STAGI NG/local_assets/downloads_pdfs/Deepwater_Horizon_Containment_Response.pdf.

256. One legal commentator observed, "That the responsible party is both an adversary and a partner may be confusing to the general public but is a direct result of the incongruent obligations imposed by [the Oil Pollution Act]." Griggs, supra note 20, at 60 .

257. For one frank, inside perspective on the ICS operation for the Deepwater Horizon response, see Epperson, supra note 227.

258. See, e.g., U.S. CoAst Guard, BP DeEPWATER Horizon Oil Spill: Incident Specific PREPAREDNESS REVIEW (ISPR) FINAL REPORT 74 (2011) ("NIMS/ICS generally worked well for this incident."); Griggs, supra note 20, at 79 ("The existing regulatory structure appears for the most part to have functioned as it was intended."). 
sponders seemed to share this same assessment that ICS worked effectively. ${ }^{259}$

\section{E. ICS Applications Today}

As the Deepwater Commission suggested, federal and state agencies have recently made efforts to establish liaisons between unified command and local communities, and they have added local officials to the federal and state officials directing operations through unified command. For example, in June 2011, the U.S. Coast Guard and the State of Washington included local officials in a full-scale exercise ${ }^{260}$ simulating response to a major oil spill in Puget Sound. ${ }^{261}$ Consistent with recommendations from both ICS practitioners and scholars, the Salish Sea exercise allowed participants to practice their ICS roles and helped instill a sense of "response community" among federal, state, and local responders in the Puget Sound area. Responding pointedly to concerns expressed by some ICS critics, ${ }^{262}$ the exercise also included simulation of coordinated support from volunteers. ${ }^{263}$

Of course, there are costs associated with inclusivity. More than a decade ago, social scientists and ICS practitioners recorded concerns with "mobilization overkill," when field operations became congested with bodies seemingly present merely to fill out organizational charts. ${ }^{264}$ Excessive elaboration of organizational structures may also create more opportunities for misplacing people within the organization. Experience with the Deepwater Horizon response, as one Coast Guard evaluator observed, demonstrated "how critical the correct use of our members in the

259. "For [EPA] Region 5, this is one of our first big incidents utilizing the Incident Command System. It's working very well." Enbridge Response, supra note 5 (statement of Steve Renninger, EPA Region 5 Planning Section Chief).

260. Such drills are specifically authorized by Congress, pursuant to Section 311 of the Clean Water Act, and suggested to include "participation by Federal, State, and local agencies" as well as private industry and responsible parties. 33 U.S.C. § 1321(j)(7) (2010).

261. The US-CAN Salish Sea 2011 exercise included more than 200 participants from the Coast Guard, EPA, Navy, the Washington Department of Ecology, county governments, and other federal, state, and local agencies, as well as Canadian counterparts. Spill Exercise US-CAN Salish Sea 2011 Conducted at NAS Whidbey Island, NAVY.MIL (June 25, 2011), available at http://www.navy.mil/search/print.asp?story_id=61220\&VIRIN=\&imagetype=0\&page=1.

262. See sources cited supra notes $102 \& 129$ and accompanying text.

263. See Wash. St. DeP'T OF ECOLOGY, US-CAN Full Scale Exercise 2011, http://www.ecy.wa.gov/programs/spills/incidents/US-CAN_SalishSeaFullScaleExercise2011/US-

CAN_SalishSeaFullScaleExercise2011.html (last visited Apr. 21, 2013) (noting bold advisement that "THIS IS A DRILL").

264. See Bigley \& Roberts, supra note 104, at 1287 (illustrating concerns from battalion chief's comments about too many bodies filling boxes and "nobody left to put out the fire"). 
right positions is to the success of the operation."265 Most recently, Professor Gregg Macey, applying organization theory to the Deepwater Horizon response, described a "paradox of organizing": while we rely upon organizations to prevent and respond to crises, organizations may themselves contribute to the cause or exacerbation of those crises. ${ }^{266}$ As prior studies have hinted, ${ }^{267}$ the paradox of organizing may never admit of any simple solutions, although it may benefit from future research by practitioners, policymakers, and academics. ${ }^{268}$

Any organizational construct will have its upsides and downsides. ${ }^{269}$ But ICS has evolved over decades of experience, learned from successes and failures, and emerged as the standard for incident management in the United States. Today, beyond simply a measure promoted by federal purse strings, ${ }^{270}$ ICS is now the law far and wide, mandated by state statutes ${ }^{271}$ and regulations, ${ }^{272}$ as well as regional compacts, ${ }^{273}$ local

265. Epperson, supra note 227, at 5. Epperson proceeds to emphasize that this systemic problem is not one likely to be resolved through additional ICS training. Epperson notes, however, that many fear such additional training will be the "likely reaction for States, local, and industry," recognizing that "it is much easier to blame training" than to alter fundamental organizational structures. Id.

266. Macey, supra note 44 , at 2068-72.

267. See, e.g., COLE, supra note 49, at 225 (noting there are "no easy answers" to questions of how to improve or even distinguish among ICS problems of system, implementation, and context).

268. Macey, supra note 44, at 2111 ("Future commissions, those who develop emergency management systems, and legal scholars should consider how this paradox could be better managed.").

269. As Cole in his 2000 evaluation of ICS pragmatically acknowledged, "there may be an unavoidable price to pay in the form of additional complications and workload" whenever expanding an organization's structure and mission in order to satisfy external demands. COLE, supra note 49 , at $220-21$.

270. See sources cited supra notes 161-62 and accompanying text (discussing HSPD-5).

271. See, e.g., ALASKa STAT. $\S \S 26.23 .077$ (a)-(b) (stating local, inter-jurisdictional, regional, and state emergency plans shall include "an incident command system that describes the respective roles of affected persons and agencies"); CAL. GOV’T CODE $§ 8670.29$ (“[O]il spill contingency plan shall . . provide for the use of an incident command system to be used during a spill."); CAL. GOV'T CODE $\S 8588.12$ (stating the terrorism awareness curriculum shall include understanding "the structure and function of an incident command system"); GA. CODE ANN. § 38-3-57 (stating the Georgia Emergency Management Agency "shall establish and maintain . . . a standardized, verifiable, performance based unified incident command system"); KAN. STAT. ANN. § 48-928(o) (stating the state division of emergency management shall "implement the use of an incident management system during emergency and disaster situations by all state, county, city and interjurisdictional disaster agencies which respond to such emergency and disaster situations"); WASH. REV. CODE $§ 38.52 .030$ (stating the state director must develop comprehensive, all-hazard emergency plan which "must specify the use of the incident command system for multiagency/multijurisdiction operations"); WASH. REV. CODE $\S 43.43 .963$ (stating the regional fire service plans "shall be consistent with the incident command system"); WASH. REV. CODE $§ 43.43 .974$ (stating the mobilization of regional law enforcement "shall be consistent with the incident command system").

272. See, e.g., CAL. CODE REGS. tit. 19, § 2405(a) ("Emergency response agencies operating at the field response level of an incident shall utilize the Incident Command System, incorporating the functions, principles and components of ICS.”); CAL. RULES OF CT. § 10.172(b)(1)(C) (“Each court 
ordinances, ${ }^{274}$ and executive orders. ${ }^{275}$ As such, ICS must be understood by those who would engage in it, as well as those lawyers and legal scholars who would competently advise clients and policymakers on how it should be considered, applied, or changed.

\section{THE ROLE OF THE LAWYER IN THE INCIDENT COMMAND SYSTEM}

\section{"[T] he law and lawyers must support. . . operations in new ways. . . ,276}

In late July 2010, as unified command on the Gulf Coast was still struggling to seal the cap on the Macondo well, the Enbridge oil spill occurred near Marshall, Michigan. As with the Deepwater Horizon response, the Enbridge spill required a massive mobilization of personnel and resources from all levels of government, as well as the responsible party, working together through unified command. ${ }^{277}$ Within six months, yet another oil spill —one of minimal volume, but with potentially grave environmental and economic implications ${ }^{278}$ - occurred in the middle of

security plan must . . . address the following general security subject areas . . . Incident command system.”); LA. ADMIN. CODE tit. 48, § 6041(C) (stating ambulance services must have a disaster plan that "shall include an incident command system that is compliant with [NIMS]"); N.Y. COMP. CODES R. \& REGS. tit. 58, § 155.7(e)(2)(v) (stating school emergency response plan "shall include . . . definition of the chain of command in a manner consistent with the National Incident Management System / Incident Command System"); WASH. ADMIN. CODE $§ 296-824-50010$ (stating businesses must ensure protection of employees from releases of hazardous substance by making sure that "a single individual, acting as the incident commander (IC), is in charge of the site-specific incident command system").

273. See, e.g., Northern Virginia Emergency Services Mutual Response Agreement 5 (2009), available at

http://www.novaregion.org/DocumentView.aspx?DID=1682 (requiring that all tactical unit and personnel responding to requests for mutual aid "shall operate in a manner in accordance with the NIMS Incident Command System").

274. See, e.g., King Cnty., Wash., Ordinance 15,114 (Feb. 1, 2005) ("The National Incident Management System is hereby adopted.").

275. See, e.g., N.Y. Exec. Order No. 26 §.26 (1996), N.Y. CoMP. CodES R. \& REgS. tit. 9, § 5.26 ("NOW, THEREFORE, I, GEORGE E. PATAKI, Governor of the State of New York . . . do hereby establish the ... Incident Command System as the State standard command and control system during emergency operations.").

276. Frederic L. Borch, Judge Advocates in Combat: Army Lawyers in Military OPERATIONS FROM VietNAM TO HAITI 319 (2001) (paraphrasing Army General George Prugh, speaking in 1974 of the role of military lawyers in military operations).

277. See sources cited supra notes $2-9$ and accompanying text.

278. Roughly $14 \%$ of the crude oil supply in the United States depends on transport by the Trans-Alaska Pipeline System (TAPS). Magill, supra note 37. Loss of this domestic supply reflected instantly in U.S. markets and beyond. See Trans Alaskan Pipeline Shuts Down, ECOWORLD (Jan. 12, 2011), http://www.ecoworld.com/energy-fuels/oil-petroleum/trans-alaskan-pipeline-shuts-downafter-spill.html (reporting the temporary shutdown of pipeline for repairs in January 2011 edged up oil prices worldwide). 
winter on Alaska's North Slope. ${ }^{279}$ Before 2011 was through, an EF5 tornado tore through the heart of Joplin, Missouri, ${ }^{280}$ massive flooding struck the Midwest, ${ }^{281}$ the Southwest experienced record fires, ${ }^{282}$ an earthquake rattled the Washington Monument, ${ }^{283}$ and Hurricane Irene swept up the Atlantic seaboard, swelling rivers from Puerto Rico to Vermont. ${ }^{284}$

The very next year, 2012, seemed determined to validate and even exceed climate change predictions by becoming the warmest year ever recorded in the United States. ${ }^{285}$ Along with this record heat, the United States experienced no less than eleven disasters in 2012 that each caused at least $\$ 1$ billion in damages. ${ }^{286}$ Among these disasters was Hurricane Sandy, which made a direct hit on New York City, devastated swaths of

279. TAPS Pump Station No. 1 oil spill was discovered by workers on the morning of January 8,2011 , with oil collecting in the basement of a pump building at the head of the pipeline on Alaska's North Slope. Repair of the leak required shutting down the 800-mile Trans-Alaska Pipeline, stopping oil production on the North Slope of approximately 630,000 barrels per day. Restart of the pipeline raised grave concerns about the loss of pipeline integrity while the pipeline idled in the bitter Arctic temperatures. See Casey Grove, Leak at Pump Station Shuts Down Pipeline, ANCHORAGE DAILY NewS (Jan. 9, 2011), http://www.adn.com/2011/01/08/1638862/pump-stationleak-shuts-down-pipeline.html.

280. The Joplin tornado, on Sunday, May 22, 2011, with winds in excess of 200 miles per hour, claimed an estimated 157 lives, making it the single deadliest tornado since modern recordkeeping began in 1950. See Preliminary Tornado Statistics Including Records Set in 2011, NAT'L OCEANIC \& ATMOSPHERIC ASS'N (Mar. 20, 2012, 12:00 PM), http://www.noaanews.noaa.gov/ 2011_tornado_information.html.

281. Flooding in 2011 struck the entire drainage of the Mississippi River, from North Dakota, through Illinois, Missouri, Mississippi, and Arkansas, to the Mississippi Delta, and east to western Kentucky and Tennessee. It was the largest flooding along the Mississippi in the past century, comparable to the Great Mississippi Flood of 1927. See 2011 Mississippi River Floods, WIKIPEDIA, http://en.wikipedia.org/wiki/2011_Mississippi_River_floods (last modified Apr. 22, 2013).

282. In 2011, Arizona, New Mexico, and Texas all experienced record fire seasons. Bob Christie, Officials: Southwest Fires Will Blaze Until July Rains, USA TODAY (July 7, 2011), available at http://www.usatoday.com/weather/wildfires/2011-06-22-arizona-southwest-wildfires-

forecast_n.htm. The record fires in New Mexico in 2011 were shortly passed by record fires in 2012. Michael Martinez, Biggest Wildfire in New Mexico's History Burns with Only 15\% Containment, CNN (June 2, 2012), http://articles.cnn.com/2012-06-02/us/us_new-mexico-historicwildfire_1_forest-service-fire-crews-fire-managers?_s=PM:US. 2012 also brought record fires in Colorado. See Jenny Deam \& John M. Glionna, Three Major Fires Wreaking Havoc in Colorado, L.A. TIMES, June 28, 2012 (noting worst fire season in Colorado history, with Waldo Canyon Fire prompting evacuation of 32,000 people in Colorado Springs area and huge High Park Fire ranging uncontrolled near Ft. Collins).

283. See Joel Achenback, 5.8 Virginia Earthquake Shakes East Coast, Rattles Residents, WASH. Post (Aug. 23, 2011), http://articles.washingtonpost.com/2011-08-23/local/35270585_1_vir ginia-earthquake-office-buildings-bill-line.

284. Crossroads of World Shuts Down and Waits, SeAtTle Times, Aug. 28, 2011, at A1 (discussing eerie quiet in New York City after evacuations ordered in advance of Hurricane Irene).

285. See Justin Gillis, Not Even Close: 2012 Was Hottest Ever in U.S., N.Y. TIMES, Jan. 9, 2013, at A1 (noting that 2012 not only shattered the previous record set in 1998, but also set 34,008 daily high records across the United States).

286. Id. 
New York and New Jersey, and caused impacts from Jamaica to Toronto, and as far west as the Ohio Valley and Wisconsin. ${ }^{287}$ The destruction wrought by Sandy was staggering, second only to Katrina seven years earlier. ${ }^{288}$ In some ways, Sandy even exceeded Katrina. For example, in terms of size, the diameter of Sandy's high winds reached more than twice that of Katrina. ${ }^{289}$ In terms of impacts, Sandy appears to have affected far more people along the dense urban East Coast than Katrina affected along the relatively rural Gulf Coast. ${ }^{290}$ And yet, while affecting more people, Sandy resulted in far fewer deaths. ${ }^{291}$ While that difference may be explained by many factors, ${ }^{292}$ part of it may have been the notable improvements in disaster response over the last seven years, ${ }^{293}$ with some improvement following from changes in disaster law itself.

As Katrina inspired the Post-Katrina Act, ${ }^{294}$ Sandy likewise inspired legislation with the Sandy Recovery Improvement Act signed into law on January $29,2013 .{ }^{295}$ To assist effectively with disaster response,

287. Eric S. Blake et al., National Hurricane Center, Tropical Cyclone Report: HURRICANE SANDY 15-19 (2013).

288. Damage estimates from Hurricane Sandy have ranged widely, up to $\$ 82$ billion according to estimates put forward by state governors in seeking federal aid. Raymond Hernandez, Congress Approves \$51 Billion in Aid for Hurricane Victims, N.Y. TIMES, Jan. 28, 2013, at A21. More modest estimates put the damage estimates from Sandy on the order of $\$ 50$ billion, still a staggering sum. BLAKE, supra note 287, at 15. For comparison, Hurricane Katrina was estimated to have resulted in $\$ 148$ billion in costs, in 2012 dollars. Andy Newman, Hurricane Sandy vs. Hurricane Katrina, N.Y. Times, Nov. 27, 2012, at A28.

289. The diameter of Katrina's high winds was approximately 400 miles, while the diameter of Sandy was 940 miles. Hurricane Irene, the year before Sandy, also exceeded Katrina, with a diameter of 520 miles. Mark Fischetti, Sandy Versus Katrina, and Irene: Monster Hurricanes by the Numbers, SCI. AM., Nov. 7, 2012.

290. As one measure of Sandy's impact, approximately 8.5 million homes lost power as a result of Sandy, compared to approximately 3 million homes due to Katrina. Newman, supra note 288.

291. Official estimates report that Sandy resulted in at least 147 direct deaths. BLAKE, supra note 287 , at 1 . This is more than ten times less than the approximately 1,836 lives lost due to Katrina. See supra note 178 and accompanying text.

292. See generally VERCHICK, supra note 171, at ch. 6 (introducing concept of "Disaster Justice," concerning the disproportionate impacts of disasters on vulnerable groups, including people of color, the poor, women, and the elderly).

293. In striking contrast with the infamously anemic government response to Hurricane Katrina, the response to Sandy received broad — even bipartisan — praise. See, e.g., Steve Vogel, Officials and Experts Praising FEMA for its Response to Hurricane Sandy, WASH. POST, Nov. 1, 2012 (quoting Republican New Jersey Governor Chris Christie as stating, "The president has been outstanding in this and so have the folks at FEMA."); see also Daniel Wolff, The Debt We Owe Katrina, N.Y. TimES, Nov. 10, 2012.

294. See Post-Katrina Act, supra note 189.

295. Sandy Recovery Improvement Act of 2013, Pub. L. No. 113-2, § 1101, 127 Stat. 4 (2012). For a summary of changes effected by this legislation, see FED. EMERGENCY MGMT. AGENCY, FACT SHEET: SANDY RECOVERY IMPROVEMENT ACT OF 2013 (2013), http://www.fema/gov/library/ viewrecord/do?id=6983. Among other significant changes, the legislation amended the Stafford Act to allow recognized tribes to make requests for federal disaster assistance directly to the President, 
lawyers and legal scholars must stay abreast of relevant, and sometimes rapid, developments in the law. However, they will also need to be prepared to address a rapid-fire series of wide-ranging legal questions that may arise early in any disaster. Consider just a few of the legal questions raised in the early days of the Katrina response: Can FEMA initiate a response without a request from the governor? ${ }^{296}$ If a responding agency deploys personnel who have not had proper immunizations, can the agency be held liable? ${ }^{297}$ Can evacuees bring their family dog to the shelter? ${ }^{298}$ Can an undocumented worker who lost his home to the hurricane seek emergency shelter from FEMA? ${ }^{299}$ What are the specific require-

instead of requiring that such requests be routed through the governor of a state. For analysis of that long-standing controversy, and the recent legislative response, see Heidi K. Adams, Sovereignty, Safety, and Security: Tribal Governments Under the Stafford and Homeland Security Acts, 1 AM. INDIAN L.J. 127 (2012); Heidi K. Adams, Sovereignty, Safety, and Sandy: Tribal Governments Gain (Some) Equal Standing Under the Hurricane Sandy Relief Act, 1 Am. InDIAN L.J. 376 (2013).

296. At the time Katrina hit, the U.S. Department of Justice Office of Legal Counsel had reportedly determined that the federal government had authority to respond even over the objection of local officials. See Ryan, supra note 206, at 529. This position is apparently consistent with the longheld (but little exercised) view of FEMA. FARBER ET AL., supra note 16, at 98. Upon review, the House criticized FEMA's reliance on a "pull" system of waiting for requests to deploy assets rather than utilizing a "push" system to deploy assets based upon need rather than just request. A FAILURE OF INITIATIVE, supra note 184, at 136-37. To clarify FEMA's authority to respond without a specific state request, Congress amended the Stafford Act to add Section 402(5), which provides that, in any major disaster, the President may "provide accelerated Federal Assistance and Federal support where necessary to save lives, prevent human suffering, or mitigate severe damage, which may be provided in the absence of a specific request." 42 U.S.C. § 5170a(5) (2010).

297. With respect to federal employees, see Federal Employees Compensation Act, 5 U.S.C. $\S$ 8101-8152 (2005). In general, with specified exceptions, "The United States shall pay compensation ... for the disability or death of an employee resulting from personal injury sustained while in the performance of his duty." 5 U.S.C. $\$ 8102$ (a).

298. At the time Hurricane Katrina hit New Orleans, with a population of 500,000 , as many as $69 \%$ of the people were pet owners. By some estimates, as many as 600,000 pets and animals were affected by the hurricane. Pets Evacuation and Transportation Standards (PETS) Act of 2005, 151 CONG. REC. E1943 (2005) (introduced) (statement of Rep. Tom Lantos). Many people reportedly risked their lives to save their pets, among other things by refusing to board evacuation buses without their pets. See Casey Chapman, Not Your Coffee Table: An Evaluation of Companion Animals as Personal Property, 38 CAP. U. L. REV. 187, 205-06 (2009). For a compelling documentary on the impacts of Hurricane Katrina on pets and prolonged efforts to return them to rightful owners, see MINE (filmmovement 2009). In response to these concerns, Congress passed the Pet Evacuation and Transportation Standards (PETS) Act of 2006, Pub. L. No. 109-38, 119 Stat. 408 (codified at 42 U.S.C. $\S \S 5196 \mathrm{~b}(\mathrm{~g})(2008))$, requiring that state and local preparedness plans "take into account the needs of individuals with household pets and service animals prior to, during, and following a major disaster or emergency."

299. Among the massive devastation wrought by Hurricane Katrina were severe impacts on immigrant communities. By one estimate, the flood following Hurricane Katrina displaced nearly 40,000 Mexican citizens living in the New Orleans area. VERCHICK, supra note 171, at 141. U.S. law generally bars non-citizens from receiving federal assistance. Personal Responsibility and Work Opportunity Reconciliation Act of 1996, Pub. L. No. 104-193, 110 Stat. 2105 (codified at 8 U.S.C. $\S 1611(\mathrm{a})-(\mathrm{c}))$. However, it allows an exception for "short-term, non-cash, in-kind disaster relief." Id. $\S 1611(\mathrm{~b})(1)(\mathrm{B})$. Reflecting that exception, FEMA issued a public notice stating, "Regardless of 
ments for providing reimbursement to states contributing mutual aid? ${ }^{300}$ What are the requirements for out-of-state healthcare professionals to practice in states where they are not licensed? ${ }^{301}$ Can contaminated floodwaters from New Orleans be pumped into Lake Pontchartrain without a discharge permit? ${ }^{302}$ For purposes of removing hurricane debris from private property, consistent with the Fourth Amendment and the Stafford Act, ${ }^{303}$ how can government agencies obtain access to private properties when the owners cannot be identified or located? ${ }^{304}$ Do re-

immigration status, all individuals impacted by Hurricanes Katrina and Rita are eligible for non-cash emergency food, water, medical care, shelter, clothing, and other urgent disaster-related needs from FEMA.” Fed. Emergency Mgmt. Agency, Disaster Assistance Available for NonCiTIZENS (2005). For a thorough analysis of the rights and limitations of immigrants receiving assistance in response to a major disaster or declared emergency, see Ashley Morey, No Shelter from the Storm: Undocumented Populations and Federal Disaster Aid, 11 SeATtLe J. Soc. Just. 257 (2012).

300. Mutual aid in response to Hurricane Katrina included deployment of more than 67,891 personnel from forty-eight states, the District of Columbia, the Virgin Islands, and Puerto Rico. A FAILURE OF INITIATIVE, supra note 184, at 144-45. State officials from Louisiana and Mississippi viewed the response as successful. Id. For an excellent introduction to the mutual aid framework and requirements, see Alan D. Cohn, Mutual Aid: Intergovernmental Agreements for Emergency Preparedness and Response, 37 URB. LAW. 1 (2005).

301. Telephone interview with Catherine Bernstein, Acting Chief Counsel, Cal. Emergency Mgmt. Agency (July 13, 2012) [hereinafter Bernstein Interview]. In general, the Emergency Management Assistance Compact, established pursuant to federal statute, Pub. L. No. 104-321 (1996), provides, "Whenever any person holds a license, certificate, or other permit issued by any state party to the compact evidencing the meeting of qualifications for professional, mechanical, or other skills, and when such assistance is requested by the receiving party state, such person shall be deemed licensed, certified, or permitted by the state requesting assistance . . . subject to such limitations and conditions as the Governor of the requesting state may prescribe . . .." Emergency Management Assistance Compact, art. V.

302. Under the Clean Water Act $\S 311$ (c), 33 U.S.C. $\$ 1321$, and implementing regulations in the National Contingency Plan, 40 C.F.R. pt. 300, discharges that are in compliance with directions from an EPA on-scene coordinator do not require a permit. See Response to 2005 Hurricanes: Frequent Questions, ENVTL. PROT. AGENCY (Aug. 13, 2009), http://www.epa.gov/katrina/ faqs.htm\#Floodi.

303. Under Stafford Act $\S 407$, no removal of debris is authorized for federal funding "unless the affected State or local government shall first arrange an unconditional authorization for removal of such debris or wreckage from public and private property." 42 U.S.C. § 5173(b) (2006).

304. To allow hurricane debris removal to proceed, state and local governments sought to obtain access by signed consent from the property owners whenever practicable. See, e.g., CITY OF GULFPORT, Miss., Right OF ENTRY AGREEMENT (on file with author). When consent proved impracticable or impossible, state and local governments obtained legal authority by other means, including invocation of state emergency powers and placement of public notices on television and in print media prior to commencing debris removal and or demolition. See, e.g., Letter from Harry P. Hewes, City Attorney, Gulfport, Miss., to William L. Carwille III, Fed. Coordinating Officer, Fed. Emergency Mgmt. Agency (Sept. 20, 2005) (on file with author). Pursuant to such approvals, in response to the vast damage from Hurricane Katrina, the U.S. EPA coordinated the collection of "white goods" including some 380,000 abandoned refrigerators, freezers, and air conditioners that could contain refrigerants potentially harmful to the environment. U.S. GOV'T ACCOUNTABILITY OFFICE, GAO-07-651, HuRricane Katrina: EPA's CURRENT AND Future ENVIRONMENTAL PRoteCtION EFForTS COULD BE ENHANCED By ADDRESSING ISSUES AND CHALLENGES FACED ON THE GULF COAST 4 (2007). 
quirements for conducting an environmental impact statement under the National Environmental Policy Act apply to siting new disposal facilities for the mountains of debris left by the hurricane? ${ }^{305}$

The stream of legal issues left in the wake of a disaster raises one more obvious question: Where are the lawyers? The legal literature on this question has been rather sparse so far, although given the major events of the past decade, it appears to be growing. ${ }^{306}$ This Part will begin to formulate answers or at least suggestions for where the lawyers are, or where they might go, in order to (1) support clients who integrate within an ICS structure, or (2) support the response directly by integrating into the ICS structure themselves. Where lawyers integrate directly into ICS, this Part will examine the various roles lawyers may serve within the ICS organization, including the emerging role of the ICS legal officer.

\section{A. The Office}

The most likely place that lawyers will support their clients during an ICS activation will be wherever those lawyers support their clients ordinarily, namely, their usual legal office. ${ }^{307}$ Staying put, as it were, has many advantages: saving the time and costs of travel; reducing the logistical pressures of providing additional workspace, meals, and lodging to another body at an incident scene; and avoiding concerns about "mobilization over-kill" and overcrowding in an incident command post. Perhaps most important, staying put will ensure the lawyer has the resources (including phones, computers, Internet access, and administrative sup-

305. See generally Stafford Act $\S 316,42$ U.S.C. $§ 5159$ (2012) (providing that NEPA environmental impact procedures are generally inapplicable to federal actions taken or funded in response to a major disaster or emergency for the specific purpose of "restoring a facility substantially to its condition prior to the disaster or emergency").

306. See, e.g., Otto J. Hetzel \& ERnest B. AbBott, Homeland Security and EMERGENCY MANAGEMENT: A LEGAL GUIDE FOR STATE AND LOCAL GOVERNMENTS (2d ed. 2010); Joseph G. Jarret \& Michele L. Lieberman, "When the Wind Blows": The Role of the Local Government Attorney Before, During, and in the Aftermath of a Disaster, 36 STETSON L. REV. 293 (2007); Nicholson, supra note 17, at 346 .

307. Of course, legal offices themselves can be impacted by disasters and other incidents. See, e.g., G.M. Filisko, What Did Katrina Teach Us?, ABA J., July 2011, at 33 (noting that almost 9,000 Louisiana lawyers were evacuated for a month or more as a result of Hurricane Katrina, and that many lawyers lost both their offices and their homes). As a result of the Katrina experience, the American Bar Association has encouraged law firms to adopt preparedness measures to ensure the protection of assets for both the firm and its clients. See, e.g., ABA COMMITTEE ON DiSASTER Response and Preparedness, Surviving a Disaster: A Lawyer's Guide to Disaster PLANNING (2011), available at http://www.americanbar.org/content/dam/aba/events/disaster/sur viving_a_disaster_a_lawyers_guide_to_disaster_planning.authcheckdam.pdf. 
port) that lawyers often need in order to provide clients with quality legal support. $^{308}$

Lawyers provide legal support to remote clients every day, assisted by advances in information technology and collaboration tools. ${ }^{309}$ In the ICS context, remote legal assistance may sometimes work well. ${ }^{310}$ However, when interacting with clients integrated within an ICS structure, a lawyer should understand at least the basics of ICS doctrine. For instance, once integrated within an ICS structure, the client may have a new position title such as Operations Section Chief or Environmental Unit Leader. Moreover, consistent with the ICS principle of unity of command, ${ }^{311}$ the client integrated within an ICS organization may have a new ICS supervisor. This means that a client's responsibilities and supervisor within the ICS context may differ from that individual's usual assigned duties and supervisor. The reality and significance of these different demands and relationships facing a client in ICS may be difficult for a lawyer to appreciate remotely, particularly for a lawyer with no concept of ICS doctrine.

But even if the remote lawyer is able to comprehend the client's different work environment, there are still particular challenges for lawyers who attempt to serve ICS clients remotely from the relative comfort of their usual offices. For one thing, it may be difficult or impossible for a lawyer to reach a client who is at the scene of a disaster, with communications channels impaired by power outages, ${ }^{312}$ downed phone lines, and remote areas that lie beyond reach of cell signals or Internet service. ${ }^{313}$ Moreover, even where communications are working fully, responders may not have the time or patience to keep their lawyers posted

308. By contrast, one trio of FEMA field counsel supporting the Hurricane Katrina response had to share a data cable in their first week, allowing each lawyer only twenty minutes of email and Internet access each hour. Fed. EMERGEncy MGMt. AgEncy, DisAster Operations LegAL REFERENCE A-28 (2011) [hereinafter DOLR].

309. See, e.g., Marc Lauritsen, Dancing in the Cloud, LAW PRAC. TODAY (Dec. 2011), http://www.americanbar.org/publications/law_practice_today_home/law_practice_today_archive/de cember11/dancing-in-the-cloud.html (discussing cloud-based information tools for attorney-client collaboration and document production).

310. Interview with Leif Palmer, Assoc. Reg'l Counsel, Envtl. Prot. Agency Region 4 (Mar. 16, 2012) (stating the incident commander "is not shy about calling me" from the command post, whenever he needs legal assistance); Telephone Interview with Bruce Jones, Assoc. Reg'l Counsel, Envtl. Prot. Agency Region 6 (Mar. 12, 2012) (stating a senior EPA official sent to the field during Hurricane Katrina response "reached back" to EPA attorney for legal advice).

311. See supra note 73 and accompanying text.

312. See Jarret \& Lieberman, supra note 306, at 312 ("[T]he power outages that accompany most disasters deny attorneys the use of electronic research, the ability to confer with colleagues, access to computer databases, and the use of other helpful resources.").

313. See Filisko, supra note 307 ("The system was challenged by the devastation to the infrastructure - no power, no cellphone signals, no working landlines." (quoting Judge Madeleine M. Landrieu on the aftermath of Hurricane Katrina)). 
on changing site conditions. Distant lawyers may, in fact, discover that their clients in the field have been engaging in activities, such as negotiations, that could have used legal assistance. As such, in order to better serve their clients, lawyers may consider leaving their offices and moving closer to the response activity.

\section{B. The Emergency Operations Center}

If not sitting in their usual offices, lawyers might step closer to the response activity by deploying to an emergency operations center (EOC) ${ }^{314}$ EOCs are facilities established by many federal, state, and local agencies, ${ }^{315}$ as well as private organizations, ${ }^{316}$ ready to activate in the event of an incident. Specifically equipped for situational awareness and communications, EOCs assist coordination among field components and external parties by facilitating exchanges of information and movement of resources. ${ }^{317}$ Deployment to an EOC may mean a modest step, perhaps only moving to a different floor within the same building, ${ }^{318}$ or it may mean moving a little farther away, for instance, to a FEMA Regional Response Coordination Center. ${ }^{319}$ Either way, work in an EOC during a

314. NIMS describes the "Emergency Operations Center" as a "physical location at which the coordination of information and resources to support incident management (on-scene operations) activities normally takes place. An EOC may be a temporary facility or may be located in a more central or permanently established facility." NIMS DoCUMENT, supra note 22, at 139.

315. Among federal agencies, the EPA maintains regional emergency operations centers colocated with the ten EPA regional offices. Among the states, the California Emergency Management Agency, for example, maintains a state-of-the-art "State Operations Center" at its headquarters within a 12.5-acre complex at the former Mather Air Force Base near Sacramento. See Operations Center, Cal. Emergency MGMt. AGENCY, http://www.calema.ca.gov/NewsandMedia/Pages/Oper ations-Center.aspx (last visited July 13, 2012). In 2009, the City of Los Angeles opened a new EOC on a ten-acre parcel in downtown Los Angeles, seismically isolated to withstand earthquakes and other threats. See Los Angeles EOC - 2009, Dispatch Mag. On-Line, http://www.911dis patch.com/info/la_eoc/ (last visited Apr. 22, 2013).

316. In the Seattle area, for example, EOCs have been established by the Boeing Company and Seattle Children's Hospital. See Katherine Beck, When Disaster Hits, BoeIng FronTIERS, May 2011, at 36, available at http://www.boeing.com/news/frontiers/archive/2011/may/i_ssg02.pdf (Boeing EOC in Renton, Washington); Interview by Jacob Hinton with Jeff Sconyers, Gen. Counsel, Seattle Children's Hosp., in Seattle, Wash. (Feb. 16, 2012).

317. See NIMS DocuMENT, supra note 22, at 66-67. Serving a coordination function, the term Emergency Operations Center may be somewhat of a misnomer, with actual operations managed in the field by the incident commander at the incident command post. Emphasizing the point, NIMS states plainly, "An EOC does not command the on-scene level of the incident." Id. at 66.

318. For example, the Regional Emergency Operations Center for EPA Region 10 in Seattle is currently four floors away from the author's EPA office.

319. Each of FEMA's ten regions maintains a Regional Response Coordination Center (RRCC), which when activated may provide a base for federal response support and help coordinate with emergency operations centers for state and local governments and other response organizations. NATIONAL RESPONSE FRAMEWORK, supra note 195, at 61. The RRCC for FEMA Region 10 is located in Bothell, Washington, a short distance outside of Seattle. 
major incident may be intense, requiring some understanding of ICS and possibly specific training. ${ }^{320}$

The EOC offers advantages to a lawyer that may not be available in the lawyer's usual office. First, operating within an EOC may put the lawyer in direct contact with elected officials, senior managers, financial officers, and other key individuals responsible for helping to coordinate a response. Second, it may provide direct communications links to the incident command post, other EOCs, and additional incident facilities and assets. Finally, it may also allow the lawyer to solely focus on legal support for the ICS activity, removing the lawyer from the daily distractions and competing demands of his usual work. For such reasons, some organizations practice and deploy legal counsel to their EOC when they are needed, ${ }^{321}$ consistent with longstanding guidance from FEMA. ${ }^{322}$

\section{The Incident Command Post}

Beyond the emergency operations center, it is possible-and perhaps increasingly likely - that a lawyer supporting a major disaster or incident may be sent to "the field," " 23 working out of a facility such as an

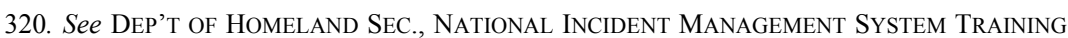
Program 59 (2011) [hereinafter NIMS TraINING PROGRAM] ("G-775: Emergency Operations Center (EOC) Management and Operations").

321. The California Emergency Management Agency, for example, has an "established position" for legal counsel within its State Operations Center in the event of an activation and has, in fact, deployed attorneys there for training exercises and real incidents such as response to the 2011 Japanese earthquake and tsunami. Bernstein Interview, supra note 300. The City of Seattle Law Department recently rotated some twenty city attorneys through its EOC during the 2012 Evergreen Earthquake exercise, and has developed a cadre of four legal "first responders" ready to deploy to the City EOC at any time. Interview with Bill McGillin, Senior Assistant City Attorney, Seattle, Wash. (July 5, 2012). For the same exercise, the Washington Attorney General's Office placed one lawyer in the state EOC and had other state lawyers on-call for support. Telephone Interview with Joe Panesko, Assistant Attorney Gen., State of Wash. (July 6, 2012) [hereinafter Panesko Interview]. The Evergreen Earthquake exercise also involved coordination among six county EOCs within the Puget Sound area, plus dozens of other federal, state, tribal, and local agencies. See Evergreen Quake 2012 Exercise Series, Wash. Military DeP'T Emergency Mgmt. Div., http:/www.emd.wa.gov/training/documents/EQESOverview04-18-12.pdf (last visited June 20, 2012).

322. Fed. EMERgency MGMt. Agency, Guide fOr All-HaZArd EMERGEnCy Operations PLANNING, at 5-A-15 (1996) ("When notified of an emergency situation, [the Legal Department] sends a representative to the EOC, if appropriate.").

323. Besides the incident command post, other "field" offices may include a joint field office (JFO), often established by federal agencies, including FEMA, to help coordinate federal, state, tribal, and local governments, along with private sector and nongovernmental organizations involved with supporting response and recovery efforts. See NATIONAL RESPONSE FRAMEWORK, supra note 195, at 62-63. Like an emergency operations center, a joint field office does not manage on-scene operations but focuses instead on providing support to the on-scene operations. See NIMS DOCUMENT, supra note 22, at 141 (defining "Joint Field Office"). Federal policy specifically contemplates the deployment of legal counsel to a joint field office. See DEP'T OF HOMELAND SEC., JOINT FIELD OFFICE ACTIVATION AND OPERATIONS 16 (ver. 8.3 2006) ("The JFO Coordination Staff 
incident command post. Only in the field may the lawyer fully grasp the situation and the response, an awareness attained by attending 6:00 a.m. shift briefings, sharing communal meals, and becoming attuned to battle rhythms. In so doing, the lawyer may discover problems that would never be reported back to the emergency operations center or senior leadership. The lawyer will see difficult decisions made on the fly every daydecisions that could benefit from legal advice - if only there was a lawyer in the house. Of course, many responders will not welcome lawyers into the house, seeing them as more of a hindrance than help. ${ }^{324}$ To prove their worth, lawyers must arrive at a command post prepared to assist the response - not just with their legal knowledge and analytical skills - but also with an ability and willingness to provide good legal advice based upon limited information and deliberation. ${ }^{325}$

Lawyers should also arrive in the field with some comprehension of the system within which they will be operating - that is, the Incident Command System. Ideally, any participants in an ICS structure will have proper training in ICS beforehand, including baseline ICS training at a minimum. ${ }^{326}$ Any person deployed to the incident command post should probably also have completed the ICS core curriculum ${ }^{327}$ plus position-

may include ... representatives providing specialized assistance in the following areas: safety, legal counsel, equal rights, and security."). Consistent with this policy, attorneys have in fact been deployed to support activities within a joint field office. See, e.g., Bernstein Interview, supra note 301 (California EMA attorney deployed to JFO in Pasadena to assist response to winter flooding in 2010); Telephone Interview with Elizabeth Cox, Assistant Reg'l Counsel, Envtl. Prot. Agency Region 9 (June 25, 2012) [hereinafter Cox Interview] (EPA attorney deployed to FEMA JFO to support response to California wildfires in fall 2007).

324. See, e.g., Nicholson, supra note 17, at 361 ("Like many Americans, [responders] may dislike attorneys, regarding them as conceited and arrogant. Overall, many believe that attorneys are a hindrance rather than an asset, and do not regard legal counsel as an important part of the [response] team.").

325. As FEMA advises its own field counsel, "It is unlikely you will have the time and information necessary to consider thoroughly all of the potential options and consequences associated with a particular decision in crisis operations." DOLR, supra note 308, at A-44. However, in riskaverse organizations, there may be a reputational trap whereby "legal actors that exercise discretion promptly seem impetuous and those that postpone action, awaiting more information, appear judicious and prudent." David A. Super, Against Flexibility, 96 CORNELl L. REv. 1375, 1466 (2011). Answering this concern, one commentator points out, "In fact, decision making is the law's principal productive activity," suggesting that exercises of discretion should be timed appropriately, responding to demand, in the same manner as other productive enterprises. Id.

326. Baseline training in ICS consists of ICS-100 and IS-700. NIMS TRAINING PROGRAM, supra note 320, at 11. ICS-100 is offered in several versions, including ICS for Health Care / Hospitals (ICS-100.HC); ICS for Higher Education (ICS-100.HE); and ICS for Law Enforcement (ICS100.LE), $i d$. at 65 , all of which are available for completion online. For a full catalog of online ICS courses, see Independent Study Program, FEMA EMERGENCY MGMT. Inst., www.training.fema.gov/IS (last visited Apr. 23, 2013).

327. The ICS core curriculum includes ICS-100; ICS-200, ICS-300, ICS-400, IS-700, and IS800. See NIMS TRAINING PROGRAM, supra note 320, at 29. 
specific coursework, as appropriate. ${ }^{328}$ Training requirements aside, lawyers in the field should be ready to help in almost any way needed. ${ }^{329}$ This Part will consider the major roles that lawyers may fill in the Incident Command System.

\section{Technical Specialist}

One place where ICS literature mentions lawyers specifically is within the planning section as a technical specialist. ${ }^{330}$ Among a diverse range of disciplines, technical specialists may include experts in explosives, forensics, faith communities, toxicology, and law. ${ }^{331}$ Technical specialists are to be activated only as needed and could be assigned to a discrete "talent pool" within the ICS planning section or sent anywhere else they are needed within the ICS organization. ${ }^{332}$

By working together within the planning section, technical specialists may benefit from interdisciplinary synergies, ${ }^{333}$ with their collective expertise and recommendations reflected in revisions to the incident action plan. Alternatively, by serving in other units within the ICS organization, legal specialists may be in the best position to gather the facts about a particular legal issue and respond with timely legal advice. In the

328. In the past, many of these training requirements may have been honored more in the breach by some organizations, although recent efforts have been made to scrutinize individual qualifications for "key leadership positions," including incident commander, public information officer, and liaison officer.

329. Such assistance may actually be a matter of law. See, e.g., CAL. Gov’T CODE $\S 3100$ ("It is hereby declared that the protection of the ... people of the state from the effects of natural, manmade, or war-caused emergencies which result in conditions of disaster . . . is of paramount state importance .... In furtherance of the exercise of the police power of the state in protection of its citizens and resources, all public employees are hereby declared to be disaster service workers subject to such disaster service activities as may be assigned to them by their superiors or by law."); see also id. § 3101 (defining "disaster service worker" to include public employees of any county, city, and state agency - with no exception for public lawyers). Even where not required by law, many lawyers would certainly volunteer to help in any way, a practice that may be encouraged by their agency or organization. See, e.g., DOLR, supra note 308, at A-14 (advising FEMA field counsel, when arriving at an EOC or JFO, to "find ways you can help, even if it does not involve the practice of law").

330. NIMS DocUMENT, supra note 22, at 105 . The title of "technical specialist" may be a bit misleading because it can encompass a broad array of disciplines, whether or not traditionally considered "technical."

331. Id. NIMS does not suggest the need for "legal counsel" with expertise in any particular area of law, but presumably a particular lawyer would not be deployed as a technical specialist unless the lawyer's specialty were well-known in advance.

332. Id.

333. For a recent argument in support of interdisciplinary collaborations involving lawyers, see Michele DeStefano, Nonlawyers Influencing Lawyers: Too Many Cooks in the Kitchen or Stone Soup?, 80 FORDHAM L. REV. 2791, 2798 (2012) (discussing recent scientific inquiries revealing that "most inventions ... primarily result from fostering diverse connections among a broad spectrum of people and professions"). 
context of an oil spill such as the Exxon Valdez or Deepwater Horizon, for example, a legal specialist might advise an operations section on how to carry out a dispersant application ${ }^{334}$ consistent with requirements of federal wildlife law. ${ }^{335}$ Similarly, one can imagine a legal specialist advising a finance section on the requirements of state law respecting mutual aid agreements. ${ }^{336}$

\section{Liaison Officer}

Higher up in the Incident Command System organization, a lawyer may capably serve as the ICS liaison officer. ${ }^{337}$ A member of the ICS command staff, the liaison officer "is Incident Command's point of contact for representatives of other governmental departments and agencies, NGOs, and/or the private sector (with no jurisdiction or legal authority) to provide input on their organization's policies, resource availability, and other incident-related matters." ${ }^{338}$ In order to provide direct input to the liaison officer, agency representatives ${ }^{339}$ and personnel from NGOs and the private sector may be assigned to the liaison officer, forming a liaison office. ${ }^{340}$

As with other command staff positions, appointment as a liaison officer presumes position-specific training ${ }^{341}$ and appropriate experience. It also appears to presume some ability to conduct legal analysis, as the liaison officer must engage in threshold questions as to which agencies or organizations have "jurisdiction or legal authority" to respond to an incident. ${ }^{342}$ Those that do have jurisdiction or legal authority to respond should participate directly in unified command. Those that do not, how-

334. For example, the EPA's ICS handbook provides, "The Legal Specialist will act in an advisory capacity," carrying out duties that may specifically include "[advising] on legal issues relating to the use of response technologies." EPA ICS HANDBOOK, supra note 61, at 9-12.

335. See, e.g., Migratory Bird Treaty Act, 16 U.S.C. $\S ~ 703-712$ (2010); Marine Mammals Protection Act, 16 U.S.C. § 1361 (2012); Endangered Species Act, 16 U.S.C. §§ 1531-1544 (2012).

336. See, e.g., Jarret \& Lieberman, supra note 306, at 317-18 (discussing the law of Florida on mutual aid agreements)

337. See supra text accompanying note 82 (explaining the general functions of a liaison officer).

338. NIMS DOCUMENT, supra note 22, at 95.

339. "Agency representative" is another designated position within ICS, defined to mean, "[a] person assigned by a primary, assisting, or cooperating Federal, State, tribal, or local government agency, or nongovernmental or private organization, that has been delegated authority to make decisions affecting that agency's or organization's participation in incident management activities following appropriate consultation with the leadership of that agency." Id. at 135. The delegation of decision-making authority distinguishes an agency representative from other interested stakeholders.

340. Id. at 95 . The liaison office is typically situated within the incident command post, near the incident commander or unified command and the public information office.

341. See NIMS Training Program, supra note 320, at 46 (E/L 956: All-Hazards Position Specific Liaison Officer).

342. See supra text accompanying note 82 . 
ever, may still have a significant role or resource to contribute to the response; as such, their involvement should be facilitated through the liaison officer. ${ }^{343}$ To determine how to involve the various agencies and organizations, the liaison officer must understand the overall incident objectives, the current needs to achieve those objectives, and the agencies or organizations that may have the resources to fill those needs. ${ }^{344}$ On the other hand, whether or not an agency or organization has resources to contribute, it may have a particular interest in the incident response. Most often, this would be the case where the agency or organization represents a community or region impacted or threatened by the incident and, as such, has a unique stake in the outcome. ${ }^{345}$

To promote effective coordination with interested stakeholders and participating agencies, the liaison officer may invite them to send representatives to the liaison office, organize and host public meetings, or send liaisons (true to the position title) to other locations, including other incident command posts and emergency operations centers. Liaison assignments to other locations may be particularly appropriate where relationships among organizations may be strained, or where incident impacts may cross sovereign territories. ${ }^{346}$ Such assignments may require the exceptional communication and diplomatic talents often associated with lawyers. ${ }^{347}$

Given the liaison officer's diplomatic functions and coordination duties, combined with the need to comprehend the legal authorities and resources of other agencies and organizations, the liaison officer position in the Incident Command System has often been staffed by a lawyer. EPA lawyers, for example, have served liaison roles for the ICS respons-

343. On this point, recall Radvanovsky's observation that one of the greatest strengths of ICS is its ability to expand or contract the ICS organization to "include other agencies and jurisdictions as needed." RADVANOVSKY, supra note 26, at 110.

344. For example, if an incident may have an impact on cultural resources, the liaison officer may need to enlist the support of a state historic preservation office or a tribal historic preservation office, consistent with requirements of the National Historic Preservation Act, 16 U.S.C. § 470(a) et seq. (2012), and implementing regulations at 36 C.F.R. § 800.1-800.16 (2013).

345. Such agencies or organizations are generally recognized as "stakeholders." ENVTL. PROT. AgENCY, INCIDENT COMMAND SYSTEM LIAISON OFFICER JOB Aid (2009).

346. In the 2011 Salish Sea exercise, for example, which simulated an oil spill on Puget Sound threatening to enter Canadian waters, a liaison was detailed from the U.S. incident command post to the command post established by the Canadian government.

347. Throughout American history, from the Founding Fathers forward, lawyers have proven success as diplomats. See, e.g., WILliam HowARD ADAMS, THOMAS JeFFERSON: THE PARIS YeARS (1997) (noting Jefferson served as minister to France from 1784-1789); DAVID MCCullough, JoHN ADAMS (2001) (noting John Adams served as an American diplomat in Europe helping negotiate a peace treaty with Great Britain, which was signed in 1782). Today, lawyers continue to fill key diplomatic posts, including the current U.S. Secretary of State (John Kerry, Boston College Law School), U.S. Ambassador to China (Gary Locke, Boston University School of Law), and the U.S. Ambassador to Canada (David Jacobson, Georgetown Law). 
es to the Enbridge oil spill in Michigan, ${ }^{348}$ along with responses to Hurricane Katrina, ${ }^{349}$ the Cosco Busan oil spill in San Francisco Bay, ${ }^{350}$ and the Salish Sea spill exercise in Puget Sound ${ }^{351}$ For the Enbridge spill in particular, where agencies and contractor personnel descended upon Marshall, Michigan, to address the massive spill into the Kalamazoo River system, EPA's Chicago region sent five EPA lawyers to serve as liaisons in two-week rotations. ${ }^{352}$ Reflecting on these experiences, lawyers recognized the value their legal training brings to the liaison position. Lawyers are "used to dealing with opposition and hostility," 353 and in the face of public pressures during a disaster response, liaison officers "must be comfortable, without getting confrontational," "354 remaining calm and focused on the mission objectives.

Service as a liaison officer, however, may bring certain challenges for lawyers. First, lawyers serving as liaison officers must remember that legal privileges that would ordinarily apply in their legal practice may not apply when engaged in an ICS response. This point may be particularly important to convey to others who may be used to working with a certain lawyer outside of the ICS context, where the attorney-client privilege may be presumed. Second, lawyers serving as liaison officers must be careful to "stay in their lane," focusing on their liaison duties, and not be tempted toward addressing legal issues. However, this focus may be difficult to maintain when other ICS participants discover "the lawyer in the house" and begin to bring that individual all manner of legal issues. ${ }^{355}$ In such cases, the lawyer can still bring value to the liaison position by identifying legal questions and then directing those questions to the proper attorneys.

348. Telephone Interview with Thomas Krueger and John Breslin, Assistant Reg'l Counsel, Envtl. Prot. Agency Region 5 (Mar. 7, 2012) [hereinafter Kruger \& Breslin Interview].

349. Interview with Wilda Cobb, Assistant Reg'l Counsel, Envtl. Prot. Agency Region 4 (Mar. 23, 2012)

350. Cox Interview, supra note 323. For background on the 2007 Cosco Busan spill, see supra note 127.

351. In the Salish Sea exercise, the author's assigned role was liaison officer, although the assignment evolved somewhat during the period of play. See infra note 355 and accompanying text.

352. Krueger \& Breslin Interview, supra note 348. Some lawyers also served more than one rotation. Id.

353. Telephone Interview with Connie Pulchalski, Assistant Reg'l Counsel, Envtl. Prot. Agency Region 5 (Mar. 9, 2012).

354. Cox Interview, supra note 323.

355. Krueger \& Breslin Interview, supra note 348. The author's own experience in the Salish Sea exercise may be illustrative. When it became known to the incident commander and others that the author was the only lawyer among over 200 participants in the exercise, the author was quickly called upon by the incident commander to provide advice on a number of legal issues arising in the oil spill scenario. 


\section{Legal Officer}

For legal practitioners and scholars, one signal development within the Incident Command System is a specific role on the command staff for lawyers: the legal officer. At this writing, the legal officer still seems to lack any explicit mention in the official literature of the National Incident Management System, but authority for appointing a legal officer can be construed from the present text of NIMS. Beyond the liaison officer, safety officer, and public information officer, NIMS recognizes that "[a]dditional Command Staff positions may also be necessary," depending on the nature of the incident or "specific requirements established by Incident Command." 356 NIMS specifically recognizes, for example, that "a legal counsel may be assigned . . . directly to the Command Staff to advise Incident Command on legal matters." ${ }^{\text {"357 }}$ When a position is created on the command staff, it carries the position title of "officer." 358 When a legal counselor assumes the title of officer, the result is a legal officer. Thus, depending on the nature of the incident and the demands of the incident commander, NIMS provides "a legal officer, or at least the potential for a legal officer, in every command post." 359

Thus far, the authority to appoint a legal officer seems little used in ICS, ${ }^{360}$ but the concept of a legal officer has deep roots in American law. For perhaps a century in the corporate world, legal officers have been among the corporate officers providing senior leadership in U.S. companies. ${ }^{361}$ In the U.S. military, lawyers have served as military officers from

356. NIMS DOCUMENT, supra note 22, at 95.

357. Id. As provided by NIMS, examples of "legal matters" justifying appointment of a legal officer specifically include "emergency proclamations, legality of evacuation orders, isolation and quarantine, and legal rights and restrictions pertaining to media access." Id. The world of legal issues that may actually justify appointing a legal officer will, of course, be far greater.

358. Id. at 92 (Table B-1). 2012).

359. Telephone Interview with Matthew Bernard, FEMA Reg'l NIMS Coordinator (June 29,

360. In the State of Washington, for example, this authority has been used "hardly ever" so far. Panesko Interview, supra note 321.

361. See, e.g., Thomas Conyngton \& R.J. Bennett, Corporation Procedure: A MANUAl FOR OFFICERS, DiRECTORS, ATtORNEYS, AND ALl OTHERS CONCERNED WiTH CORPORATE MANAGEMENT 338 (1922) (noting by-laws of U.S. Steel Corporation that established the general counsel as the "chief consulting officer of the company in all legal matters"). More recently, alongside the Chief Executive Officer, Chief Financial Officer, and other corporate officers, corporations have begun to establish the position of Chief Legal Officer, a move that may connote both a broader portfolio among company affairs and elevated rank over the traditional general counsel. See Rees Morrison, What's the Difference Between General Counsel and Chief Legal Officer?, LEGAL DEP'T MGMT. (Mar. 22, 2006, 6:21 AM), http://lawdepartmentmanage ment.typepad.com/law_department_management/2006/03/whats_ the_diffe.html ("CLO also elevates the legal leader to the so-called C-Suite, the titular peer of the Chief Financial Officer . . . , Chief Technology Officer... and others in the executive teepee."). 
the beginning of the republic, ${ }^{362}$ commanding troops and even seeing the face of combat at times. ${ }^{363}$ Over the last half century, the role of legal officers in support of combat operations has evolved considerably, and today it may provide an instructive model for the increasing role of legal officers in support of ICS operations. Legal officers in the military have long been called upon to provide legal counsel for military members across the full spectrum of legal affairs, a general legal practice that continues today. ${ }^{364}$ Particularly since the Vietnam War, legal officers have also become increasingly engaged with direct support for military operations, contributing to the new legal discipline of "operational law." 365

The practice of operational law would include many elements now familiar in the ICS context. These elements included recognition that lawyers "had to take their legal services to the field" "366 and specifically "had to be located with commanders during a deployment." " provide commanders with good advice, these lawyers had to be "operations smart," able to understand both the mission objectives and the operational system for meeting those objectives. ${ }^{368}$ Operational lawyers had

362. Thomas Jefferson served with the rank of colonel during the Revolutionary War, a war that Jefferson personally helped to start by drafting of the Declaration of Independence. DUMAS MALONE, JeFFERSON, THE ViRGiniAn 140, 291 (1948).

363. During World War II, for example, Army lawyer Samuel Spitzer was awarded a Silver Star for a courageous act that resulted in the capture of more than 500 German soldiers. In the Korean War, Army lawyer Bruce C. Babbitt took command of a rear perimeter defense after the front collapsed during a Chinese attack, and successfully repulsed the enemy attack. In later combat operations, Army lawyers accompanied the first wave of U.S. troops on the October 25, 1983, assault on Grenada in Operation Urgent Fury and parachuted into combat in Panama in the 1989 Operation Just Cause. BORCH, supra note 276, at 62, 315, 321 .

364. See U.S. ARMY CTR. FOR LAW AND Military Operations, Forged IN Fire: LegaL LESSONS LEARNED DURING MILITARY OPERATIONS 1994-2008 (2008) [hereinafter FORGED IN FIRE] (describing broad areas of judge advocate legal support including contracting, fiscal controls, environmental compliance, estate planning, landlord-tenant issues, vehicle repossessions, and disaster relief, as well as Law of War, Rules of Engagement, Courts-Martial, and other areas more closely associated with military jurisprudence).

365. BORCH, supra note 276 , at 313 . Borch, in his analysis of military operations from Vietnam (1959) to Haiti (1996), identifies four causes for this development: (1) the changing nature of warfare involving new technologies, humanitarian missions, and less-identifiable enemies; (2) the individual initiative of legal officers who were better educated, energetic, creative, and less fixed on traditional notions of lawyering; (3) new directives for ensuring military operations comply with the rule of law; and (4) the 1983 experience in Grenada, which resulted in institutional recognition of the need for field deployment of legal officers. See id. at 312-21.

366. Id. at 317 .

367. Id. at $320-21$.

368. Id. This point was also emphasized by one current military officer, who explained that the legal officer had to be in constant contact with the Commander in order to understand the Commander's goals and to provide the Commander with the best advice on how to meet those goals. Interview by Jacob Hinton with Treb Courie, Major, U.S. Army, in Fort Lewis, Wash. (Apr. 13, 2012) [hereinafter Courie Interview]. 
to bring the requisite training, ${ }^{369}$ of course, including expertise in certain areas of practice, where needed. ${ }^{370}$ Operational lawyers had to provide legal support that was timely, accurate, and often creative. ${ }^{371}$ Finally, in support of mission objectives, lawyers on the front lines of operations had to be prepared to step out of traditional lawyer roles and serve other functions, such as a public affairs officer ${ }^{372}$ or liaison officer, ${ }^{373}$ as needed.

As a result of these demands upon their legal counsel and the expanded roles their counsel served in military operations, commanders and missions reaped substantial rewards. In Panama, for example, military lawyers addressed a problem of prolific firearms in the country by drafting a "guns-for-cash" policy, which resulted in the efficient removal of more than 8,000 weapons. ${ }^{374}$ Later, in Iraq, military lawyers helped navigate a complex body of customary and codified international law and military regulations to devise a program that would allow commanders to retain Iraqi currency captured by U.S. troops and apply such proceeds directly to humanitarian needs of the Iraqi people. ${ }^{375}$ Considering all the successes of integrating lawyers into military operations, one military historian concluded that legal officers had become "a key member of the commander's staff" and "more relevant and essential" to the military organization. ${ }^{376}$ Confirming this historical perspective, one current military officer suggested that it was "more important than ever for Commanders in the field to have a legal advisor." 377

369. Among training that operational lawyers may now receive is training in ICS in order to support domestic operations including responses to chemical, biological, or nuclear attack. Id.

370. For example, the need for additional military equipment and supplies in combat operations during Operation Desert Storm was noted to require the services of experts in contracts and fiscal law. BORCH, supra note 276, at 323.

371. Id.

372. Id. at 325 (army lawyer serving as "public affairs officer" in Haiti during Operation Uphold Democracy, 1994-1995). Civilian agencies have also recognized that lawyers can apply their polished speaking and writing skills within ICS public information offices. Cobb Interview, supra note 349 (in addition to serving as liaison officer on some incidents, EPA attorney Cobb also served in public information offices during ICS responses to Hurricane Katrina and the Columbia space shuttle disaster).

373. BORCH, supra note 276, at 313-14, 318 (noting that an Army lawyer, as "principal liaison officer," engaged in diplomatic discussions with Viet Cong and South Vietnamese during Vietnam War); see also FORGED IN FIRE, supra note 364, at 367 ("Commands will often call upon [lawyers] to act as the command's "professional liaison officer."').

374. BORCH, supra note 276, at 321.

375. FORGED IN FIRE, supra note 364, at 221-23. This program, known as the Commander's Emergency Response Program, involved the redistribution of more than one billion dollars of Iraqi currency, consistent with defined criteria, and supporting basic Iraqi needs such as healthcare, education, irrigation, sanitation, vehicle repair, and the rule of law. Id.

376. BORCH, supra note 276 , at 322.

377. Courie Interview, supra note 368 . 
Perhaps because of this military success with lawyers in combat operations, the military has appeared on the forefront of embracing the use of legal officers in Incident Command System operations. ${ }^{378}$ Among other applications, this policy appears in the area contingency plans ${ }^{379}$ prepared by the U.S. Coast Guard and other agencies consistent with the National Oil and Hazardous Substances Pollution Contingency Plan. ${ }^{380}$ Extending this concept to an international level, the policy of including a legal officer on the ICS command staff has also been adopted in bilateral agreements between the United States and Canada for coordinating responses to oil and hazardous substance spills. ${ }^{381}$ Beyond just words and figures on paper, these plans have in fact been implemented in response to recent spills, including the Deepwater Horizon.

For the Deepwater Horizon response, the Coast Guard established a legal office with six lawyers among the some 400 personnel deployed to Unified Area Command in New Orleans. ${ }^{382}$ Working sixteen-hour days, the lawyers in unified command wrestled with rapid-fire response issues such as the application of subsurface dispersants, compliance with the Endangered Species Act, transportation and disposal of solid wastes, relations with state and local elected officials, marine safety, property management, records management, and any other legal issues that demanded their attention. ${ }^{383}$ In addition to Coast Guard lawyers, there were lawyers within Unified Area Command representing other agencies and private organizations, including BP. ${ }^{384}$ There were also lawyers for various agencies and organizations sprinkled throughout the Area Command, including the incident command posts in Houston, Houma, and Mobile.

378. See, e.g., Dep't of Defense, Nuclear Weapons Accident Response Procedures (DoD 3150.8-M), InCident Command System Functional App. 1-4. The DoD procedures specifically identify the Legal Officer as a member of the Command Staff and define the Legal Officer's responsibilities to include "providing legal advice to the DoD [incident commander] or [unified command] and the staff, as well as ensuring all plans ... policies, and directives are consistent with military, and Federal, State, local, and tribal law." The Legal Officer's responsibilities also include ensuring that accurate records are properly maintained, working closely with the documentation unit of the planning section. Finally, in the context of nuclear weapons accidents, the DoD procedures provide that the Legal Officer "should be very familiar with CERCLA." Id. at 4.

379. See, e.g., Alaska Reg'l Response Team, Unified Plan: The Alaska Federal/State PREPAREDNESS Plan For RESPONSE to OIl and HaZARdous Substance Discharges/Releases, at B-16, B-29 fig. 5 (2010) (including legal officer among command staff).

380. See supra note 134 and accompanying text (discussing the National Contingency Plan).

381. See CANUSWESt, Regional AnNex: CANADA-United States Joint InLAND Pollution Contingency Plan 11 (1998) (“The IC's Command Staff consists of a Safety Officer, a Liaison Officer, a Legal Officer and a Public Information Officer.").

382. Interview with Mike Lodge, former U.S. Coast Guard Legal Officer (Mar. 16, 2012).

383. Id.

384. Telephone Interview with private attorney who wished to remain unnamed (May 25, 2012). 
Like the Coast Guard lawyers, BP lawyers supporting the Deepwater Horizon response had to grapple with rapid-fire demands including reviewing draft documents, seeking regulatory approvals, and initiating funding mechanisms. ${ }^{385}$ BP lawyers also addressed issues including labor, finance, real estate, and the Vessels of Opportunity program. ${ }^{386}$ As a large corporation, BP had the benefit of experience from dealing, in its own way, with other major incidents, including 9/11 and Hurricane Katrina. ${ }^{387}$ For the Deepwater Horizon, BP also had the benefit of a crisis management system modeled upon the Incident Command System. ${ }^{388}$

Environmentalists and commentators may speculate endlessly about BP's motives for participating as it did in the massive response to the Deepwater Horizon disaster. ${ }^{389}$ However, given the scope of liability that this incident presented to the company, it is hard to imagine any rational chief executive who would not want the benefit of legal counsel engaged directly in looking after the company's interests in the response. For many of the same reasons that the U.S. military discerned the need for lawyers in combat operations and the Coast Guard wrote legal officers into their contingency plans, the private sector could readily see the value of having lawyers in the field where decisions are being made that affect private interests. ${ }^{390}$ This same conclusion supporting the use of legal officers in ICS appears to have been reached as well by other companies, ${ }^{391}$ civilian agencies, ${ }^{392}$ and even elements of the judiciary. ${ }^{393}$

385. Id.

386. Id. On the Vessels of Opportunity program, see FACTSHEET ON BP VeSSELS OF OPPORTUNITY PROGRAM (2010) [hereinafter FACTSHEET ON BP], available at http://www.bp.com/liveassets/bp_internet/globalbp/globalbp_uk_english/incident_response/STAGI NG/local_assets/downloads_pdfs/factsheet_bp_vessels_of_opportunity_program.pdf (noting that at that time, around 3,000 local vessels were already participating in the program, contracted to help contain the oil spread through activities including skimming, tending, and maintaining boom, and transporting supplies, personnel, and wildlife as part of the response).

387. For example, on 9/11, BP had employees scattered around the world, and BP lawyers assisted with efforts to bring them home safely after the airlines shut down. Later, in response to Hurricanes Katrina and Rita, BP lawyers assisted efforts to help protect BP interests in the Gulf of Mexico. Telephone Interview with private attorney, supra note 384.

388. Id. (noting that the ICS structure for Deepwater Horizon was "not alien" to the company).

389. For a tour de force of speculation on this question, see William H. Rodgers Jr., Jason DeRosa \& Sarah Reyneveld, Stranger Than Fiction: An "Inside" Look at Environmental Liability and Defense Strategy in the Deepwater Horizon Aftermath, 1 WASH. J. ENVTL. L. \& POL'Y 219 (2011) (offering a tongue-in-cheek imaginative scenario of advice from BP's in-house counsel on how the company should control costs by taking over and managing the entire Gulf oil spill response under the ICS structure of unified command).

390. Applying economic analysis to advocate a role for lawyers in disaster response, one commentator concluded that "postponed legal decisions often have considerably less value than a decision made earlier." Super, supra note 325, at 1380.

391. The Alyeska Pipeline Service Company, for example, deployed legal counsel to the incident command post established in response to the January 2011 oil leak at the Trans-Alaska Pipeline 
One federal agency with an established practice of deploying legal officers is FEMA, which over the last twenty years has developed a cadre of field counsel ready to deploy and provide command staff with legal advice whenever and wherever needed. ${ }^{394}$ Of course, on the front line of any major incident will be representatives of state, tribal, and local government, with local governments most often providing the first responders. Recognizing that "local government plays the vital first response role with regard to disasters," commentators have noted that local emergency managers "must have access to competent legal counsel on a continuing basis." ${ }^{, 395}$ Ensuring the availability of legal counsel with competence in disaster and emergency management is not easy on any level of government, but may pose particular issues for the many communities that do not have full-time legal staff. ${ }^{396}$

One significant challenge now for lawyers of any stripe who may be called upon by an incident commander to serve as legal officers in an Incident Command System activation is to locate available training and resources that will help the lawyer prepare for this assignment. So far, neither FEMA nor any other agency or organization appears to offer ICS training specifically for legal officers. ${ }^{397}$ Such training should be devel-

System (TAPS) Pump Station No. 1 on Alaska's North Slope. See AlyeSKa PIPEline SerV. Co., INCIDENT ACTION PLAN, ICS 207 ORG CHART (2011) (on file with author).

392. For the TAPS Pump Station No. 1 incident, the U.S. EPA deployed several personnel to the incident command post, including the author as legal officer. Id.

393. For example, in response to the Occupy Seattle protests in early 2012, the Western District of Washington developed "Operation Peace Keeper," combining resources from local and federal law enforcement agencies and including an Assistant U.S. Attorney as a legal officer in the command structure. See InCident Action Plan, Operation PeAce KeEPER (2012) (on file with author).

394. Fed. Emergency Mgmt. Agency, Disaster Operations Legal Reference 4-23 (2011). In its literature, FEMA does not refer to its field counsel as "legal officers," but they appear to serve the same functions. Formerly associated with the ICS planning section, they now serve primarily within the ICS command staff, advising the federal coordinating officers who often serve as incident commanders. Interview with Mary Ellen Martinet, Assoc. Chief Counsel, Fed. Emergency Mgmt. Agency Office of Chief Counsel (July 27, 2012). Core competencies for FEMA field counsel also explicitly include, "Understand, use, and comply with Incident Command System (ICS) concepts, principles, and process." FEMA OfFICE OF CHIEF COUNSEL, DePloyABLE Field COUNSEL TRAINING CURRICULUM 62 (2012).

395. Nicholson, supra note 17, at 354.

396. See id. at 356. Iowa, for example, was reported to have fifty-seven communities represented by full-time legal staff and forty-two communities represented by part-time legal staff. Id.

397. FEMA has developed training courses for its own field counsel, which lawyers from other agencies may be able to attend. Bernstein Interview, supra note 301 (California EMA attorneys attending FEMA training). For fiscal year 2013, FEMA's Emergency Management Institute (EMI) course offerings include Introduction to FEMA Office of Chief Counsel (OCC) Field Operations Response, Recovery, and OCC Cadre Deployment (E/L 711); and Advanced Field Attorney Training (E714). For the full course catalog, see Emergency Management Institute, FED. EMERGENCY MGMT. AGENCY, http://training.fema.gov/emi (last updated Apr. 11, 2013). Beyond FEMA, individual efforts have also been made to provide such legal training, including a workshop, "The Law and 
oped and included among FEMA's "mobile training courses" offered regularly around the country and even internationally. ${ }^{398}$ For now, lawyers who may be deployed in an ICS activation should avail themselves of other appropriate ICS courses, including quick baseline courses that are available online without charge. ${ }^{399}$

Like the current training for legal officers, the literature for legal officers remains undeveloped. This Article may provide one starting point within legal scholarship. ${ }^{400}$ However, the need for a literature to help define the role of lawyers within ICS activations has been recently recognized by significant publications from FEMA ${ }^{401}$ and others within the emergency management community. ${ }^{402}$ As incident commanders increasingly recognize the value of legal officers on their command staff, the demand for guidance and training in these positions can be anticipated to grow as well. Moreover, as lawyers gain experience serving in other ICS positions, including as liaison officers and technical specialists, the cadre of field-tested lawyers will continue to grow, deepening the pool of legal talent available to serve all legal needs for any future ICS activation.

Catastrophic Disasters: Legal Issues in the Aftermath," offered in 2009 in conjunction with a meeting of the National Emergency Management Association (NEMA) and NEMA's Legal Attorneys Committee. While the workshop attracted state attorneys, costs of registration and travel reportedly resulted in few local attorneys in attendance. Nicholson, supra note 17, at 365 n.101.

398. Unlike hundreds of courses on other subjects offered by FEMA across the country in fiscal year 2013, including twelve offerings of NIMS ICS All-Hazards Liaison Officer, only three courses for lawyers were offered in fiscal year 2013, and none were offered outside of Washington, D.C. See Resident Courses (On-Campus), Fed. Emergency Mgmt. Agency, http://training. fema.gov/emicourses (last updated Nov. 8, 2012).

399. See supra note 326 (ICS-100, IS-700 available online).

400. To the author's knowledge, this Article is the first time the legal officer concept within ICS has been recognized within legal academic work. However, Professor Nicholson accurately identified the NIMS authority for a legal officer in his 2010 law review article. See Nicholson, supra note 17 , at $350-51$.

401. In November 2011, FEMA's Office of Chief Counsel published Version 1.0 of the Disaster Operations Legal Reference, a substantial volume collecting laws, regulations, guidance, and lessons learned from twenty years of experience with FEMA field counsel, while attempting to dispel "urban myths" that have grown up around the same. It is intended to remain as a living document, capturing future lessons and remaining current with new law and legal interpretations. FED. EMERGENCY MGMT. AGENCY, DisASTER OPERATIONS LEGAL REFERENCE vii-viii (2011).

402. In 2011, the first known description of specific duties for an ICS legal officer appeared in publication. See Tim Deal, Chuck Mills \& Mike Deal, All Hazard Field Guide: A RESPONDER'S HANDBOOK USING THE NATIONAL INCIDENT MANAGEMENT SYSTEM'S INCIDENT COMMAND SYSTEM 7-12 (2011). According to this source, some of the major duties of an ICS legal officer may include the following: obtaining a briefing from the incident commander or unified command; assigning tasks and supervising legal staff; attending required meetings, prepared to discuss legal issues; providing legal advice to command and other ICS staff; reviewing agreements and contracts; ensuring documentation meets established requirements; helping resolve labor issues; responding to ethics issues; working with the liaison officer to help resolve interagency concerns; working with the finance section to help resolve contractor disputes; and reviewing all plans to ensure compliance with legal mandates. 


\section{CONCLUSION}

While lawyers can make substantial contributions to Incident Command System responses, the expanding use of ICS also raises fundamental questions in diverse areas of law including legal ethics, torts, corporations, and employment law. As a matter of legal ethics, for example, who is the "client" of an ICS legal officer? ${ }^{403}$ Is it simply the lawyer's usual client outside of the ICS response, ${ }^{404}$ or is it possibly the ICS incident commander or the ICS organization itself ${ }^{405}$ As a matter of torts, can failure to implement ICS properly result in civil liability? ${ }^{406}$ As a matter of corporate law, what is the legal status of an ICS organization? Can it sue or be sued? ${ }^{407}$ As a matter of employment law, can personnel

403. The answer to this single question obviously carries profound implications for compliance with numerous rules of professional conduct. The lawyer, for example, owes a client the duty of competent representation, MODEL RULES OF PROF'L CONDUCT $\S 1.1$, and must ordinarily abide by a client's decisions, id. $\S 1.2$ (a). A lawyer must preserve client confidences, $i d$. $\S 1.6$, and must seek to avoid conflicts among clients, $i d$. $\S 1.7$. Perhaps most significant for lawyers deployed to the field, a lawyer, in representing a client, "shall not communicate about the subject of the representation with a party the lawyer knows to be represented by another lawyer in the matter," unless certain circumstances apply. Id. $\S 4.2$

404. Even without the overlay of ICS, the question of "Who is the client?" may prove confounding under ordinary circumstances. For government lawyers, the Model Rules of Professional Conduct offer little more than an intellectual shrug: "Defining precisely the identity of the client and prescribing the resulting obligations of such lawyers may be more difficult in the government context and is a matter beyond the scope of these Rules." MOdEL RULES OF PROF’L CONDUCT $\S 1.13$, cmt. 9; see also William R. Dailey, Who Is the Attorney General's Client?, 87 NOTRE DAME L. REV. 1113 (2012) (positing that the client of the Attorney General "is the American people," but recognizing that the interests of the American people require "mediation" through spokesmen including the President and Congressional acts).

405. See MODEL RULES OF PROF’L CONDUCT $§ 1.13$ (a) (“A lawyer employed or retained by an organization represents the organization acting through its duly authorized constituents.").

406. See, e.g., Donna Prince L. v. Waters, 48 A.D.3d 1137, 1139, 2008 N.Y. Slip Op. 00879 (2008) ("[ICS] may form the predicate for liability . . . because it "mandates a reasonably defined and precedentially developed standard of care."') (citations omitted). For background and analysis of this case, see Bradley M. Pinsky, NIMS Directives and Liability, FIRE ENGINEERING, Mar. 2009; see also Cohn, supra note 300, at 17 (discussing cases including Buttram v. United States, where two volunteer firefighters died while fighting a fire in an ICS activation commanded by U.S. Bureau of Land Management); Buttram v. United States, Civ. Case No. 9609234-S-BLW (D. Idaho, Feb. 19, 1999), available at http://www.idd.uscourts.gov/ECM/dc_images/_1DVOTAYE810007907.pdf (granting judgment in favor of plaintiffs against the United States).

407. Early cases on this question suggest the matter is far from decided. Two cases illustrate the irresolution of the law on this question. Brassinga v. City of Mountain View, 66 Cal. App. 4th 195 (Cal. Ct. App. 1998), and Berger v. Mead, 338 N.W.2d 919 (Mich. Ct. App. 1983), both involved cases of city police officers injured while participating in training with regional SWAT teams. In Brassinga, the California court found that the regional tactical team, while employing a unified command structure, was not an entity that could qualify as an employer subject to suit or worker's compensation claim. Brassinga, 66 Cal. App. 4th at 210-11. In Berger, the Michigan court reached the opposite conclusion, holding that the tactical team was a "joint venture" under Michigan law. In reaching this conclusion, the court noted that "[t]he key consideration is that the parties intended a joint venture." Berger, 338 N.W.2d at 922. For further analysis of these contrasting cases, see Cohn, supra note 300, at 48-50. 
deployed to serve in an ICS response become the employee of the ICS organization $?^{408}$ These and many other legal questions raised by ICS doctrine remain for lawyers, jurists, and legal scholars to consider and resolve.

At the same time that lawyers begin to reflect systematically upon these questions raised by ICS, they may also become pulled into ICS themselves, either by supporting clients who deploy in ICS, or by deploying directly. Early experience with lawyers in military combat and more recently in major incidents, such as the Deepwater Horizon and the Enbridge spill in Michigan, suggests that lawyers may bring significant value to field operations. However, before deploying to the field, or attempting to assist clients who are deployed, lawyers should acquire some basic comprehension of ICS doctrine.

Through tragic events including 9/11 and Hurricane Katrina, we have seen the consequences of failure in command and coordination. More recently, however, we have seen the success that preparation and organization can bring, as with the timely response to Hurricane Sandy. ${ }^{409}$ Contributing to this success is the recent widespread adoption of the Incident Command System. Today, ICS has been embraced by federal agencies; by state, tribal, and local governments; and by the private sector, schools, and nonprofit organizations. For lawyers, these entities represent a large number of clients, and these clients will need lawyers who are both able and willing to provide timely and competent advice when disasters strike. Through training in ICS and critical analysis of questions raised by ICS doctrine, legal practitioners and scholars can be better prepared to serve their clients and the public interest when urgent needs arise in our restless world and changing climate.

408. At common law, an employer may "borrow" an employee from a primary employer for special purposes. The employee may then become a "special employee" of the special employer, with implications including worker's compensation claims and potential tort liability for the special employer under the theory of respondeat superior. 30 C.J.S. Employer-Employee $§ 217$ (2012). In the specific context of ICS, see Roma v. United States, 344 F.3d 352 (3rd Cir. 2003). Roma involved an application of ICS for coordinating a response by multiple fire companies to a major fire at a U.S. naval facility. Upon review, the appellate court found that a volunteer firefighter called to assist the Navy through a mutual aid agreement became a "paradigmatic example of a special employee." Id. at 364. For a contrasting result, see Enslow Through Enslow v. United States, 1994 WL 649979 (9th Cir. 1994) (unpublished decision), where the appellate court found that a California state firefighter did not become a special employee of the U.S. Forest Service when called by the Forest Service to respond to a fire in a national forest.

409. See supra note 293 and accompanying text (noting the broad, bipartisan praise for the government's response to Hurricane Sandy). 